\title{
HIV-1 Protease Inhibitors Incorporating Stereochemically Defined P2' Ligands To Optimize Hydrogen Bonding in the Substrate Envelope
}

\author{
Linah N. Rusere, ${ }^{\dagger, \S}$ Gordon J. Lockbaum, ${ }^{\dagger, \S \odot ~ S o o k-K y u n g ~ L e e, ~}{ }^{\dagger}$ Mina Henes, $^{\dagger}$ Klajdi Kosovrasti, $^{\dagger}$ \\ Ean Spielvogel, ${ }^{\ddagger}$ Ellen A. Nalivaika, ${ }^{\dagger}$ Ronald Swanstrom, ${ }^{\dagger}$ Nese Kurt Yilmaz, ${ }^{\dagger}$ Celia A. Schiffer, ${ }^{*},{ }^{\dagger}$ \\ and Akbar Ali*,†॰
} ${ }^{\dagger}$ Department of Biochemistry and Molecular Pharmacology, University of Massachusetts Medical School, Worcester, Massachusetts
01605, United States
${ }^{\ddagger}$ Department of Biochemistry and Biophysics, and the UNC Center for AIDS Research, University of North Carolina at Chapel Hill,
Chapel Hill, North Carolina 27599, United States

\begin{abstract}
A structure-guided design strategy was used to improve the resistance profile of HIV-1 protease inhibitors by optimizing hydrogen bonding and van der Waals interactions with the protease while staying within the substrate envelope. Stereoisomers of 4-(1-hydroxyethyl)benzene and 4-(1,2dihydroxyethyl)benzene moieties were explored as $\mathrm{P} 2{ }^{\prime}$ ligands providing pairs of diastereoisomers epimeric at $\mathrm{P} 2{ }^{\prime}$, which exhibited distinct potency profiles depending on the configuration of the hydroxyl group and size of the $\mathrm{P} 1^{\prime}$ group. While compounds with the 4-(1-hydroxyethyl)benzene P2' moiety maintained excellent antiviral potency against a panel of multidrug-resistant HIV-1 strains, analogues with the polar 4(1,2-dihydroxyethyl)benzene moiety were less potent, and only the $(R)$-epimer incorporating a larger 2-ethylbutyl P1' group showed improved potency. Crystal structures of proteaseinhibitor complexes revealed strong hydrogen bonding interactions of both $(R)$ - and $(S)$-stereoisomers of the hydroxyethyl group with Asp30'. Notably, the $(R)$-dihydroxyethyl group was involved in a unique pattern of direct hydrogen bonding interactions with the backbone amides of Asp29' and Asp30'. The SAR data and analysis of crystal structures provide insights for optimizing these promising HIV-1 protease inhibitors.
\end{abstract}

\section{INTRODUCTION}

The HIV-1 protease is a major target for developing antiviral therapies against HIV-1. Drug discovery efforts, aided by structure-based drug design, have led to the development of nine FDA-approved HIV-1 protease inhibitors (PIs). ${ }^{1}$ All approved HIV-1 PIs are competitive inhibitors, and most contain different dipeptide isosteres as transition state mimetics. ${ }^{2}$ In addition to extensive hydrophobic interactions, PIs mainly rely on a number of direct and water-mediated hydrogen bonds with the protease for potency. The clinical efficacy of HIV-1 PIs has significantly improved since this drug class was first introduced in the mid-1990s. The development of second-generation PIs with improved potency, tolerability, and pharmacokinetic profiles and the introduction of low-dose ritonavir as a pharmacokinetic booster in PI-based antiretroviral therapy (ART) have led to improved clinical outcomes. Moreover, PIs allow an exceedingly high level of viral inhibition at clinical concentrations due to cooperative dose-response curves with high slopes. ${ }^{3,4}$ These transition- state mimetic inhibitors represent the most potent anti-HIV-1 drugs.

Despite much success, PI-based therapies are associated with drawbacks that limit their effectiveness, including major side effects, unfavorable pharmacokinetics, and the acquisition of many viable multidrug-resistant (MDR) protease variants. ${ }^{5,6}$ Drug resistance remains a major issue, as the prevalence of PI resistance mutations increases with duration of ART and is much higher among PI-experienced patients. ${ }^{7,8}$ Even the most effective PI-based regimens have been reported to select multiple resistance mutations in the protease, resulting in reduced virologic response. ${ }^{7-10}$ Moreover, the prevalence of transmitted drug resistance continues to increase, which is an added challenge in the treatment of HIV infections. ${ }^{11,12}$ The emergence of MDR protease variants presents a challenge to structure-based drug design (SBDD), as the target is not a single protein but an ensemble of closely related proteases. The

Received: May 23, 2019

Published: August 6, 2019 
new PIs must maintain activity not only against existing MDR protease variants but also against future variants that may emerge. These challenges require developing new SBDD strategies to optimize PI potency while avoiding resistance.

The design strategy to maximize interactions in the HIV-1 protease active site, particularly with the protein backbone atoms, has been quite successful, leading to the development of the FDA-approved drug darunavir. ${ }^{13,14}$ Darunavir (DRV, $\mathbf{1}$ ) is a highly potent inhibitor of HIV-1 protease with a low $\mathrm{pM}$ inhibition constant $\left(K_{\mathrm{i}}\right)$ and a high genetic barrier to resistance. The key structural feature that distinguishes DRV from previous generation HIV-1 PIs is the bis-tetrahydrofuran (bis-THF) moiety at the P2 position (Figure 1) that makes
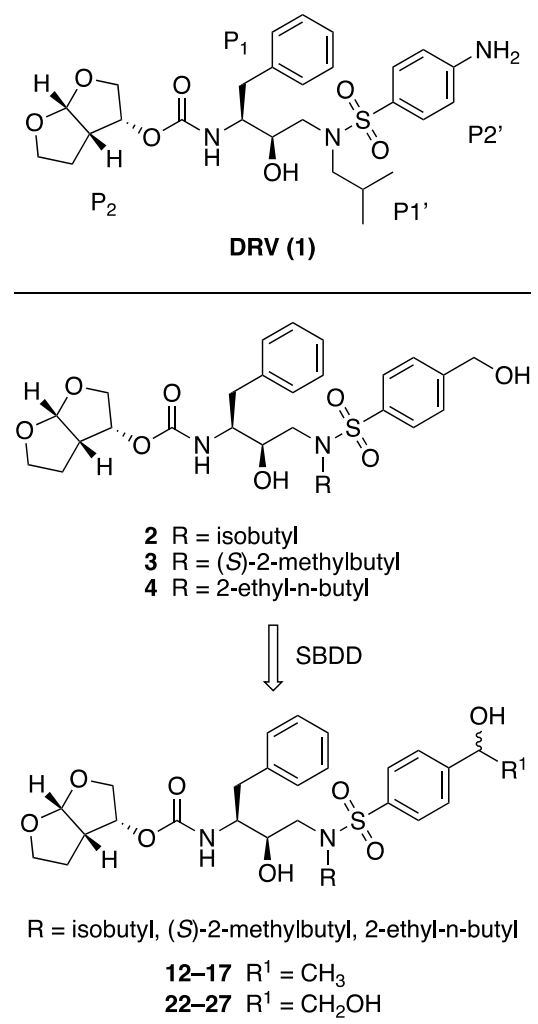

Figure 1. Structures of HIV protease inhibitors DRV (1), P2' 4-(1hydroxymethyl)benzene analogues (2-4), and designed compounds with stereochemically defined P2' 4-(1-hydroxyethyl)benzene and (12-17) and 4-(1,2-dihydroxyethyl)benzene (22-27) moieties. The canonical nomenclature for the inhibitor moiety position is indicated using DRV.

strong hydrogen bonding interactions with the backbone $\mathrm{NH}$ of Asp29 and Asp30 in the protease active site. ${ }^{1,13,15}$ The application of the design strategy to maximize interactions with the backbone atoms of HIV-1 protease has recently led to the discovery of DRV analogues that maintain exceptional potency against MDR HIV-1 variants including DRV-resistant strains. $^{16-19}$

Among the strategies proposed to rationally design PIs against drug-resistant HIV-1 variants, the substrate envelope model provides a more comprehensive framework to incorporate drug resistance considerations into SBDD. ${ }^{20-22}$ This structure-guided design strategy aims to optimize hydrogen bonding and van der Waals (vdW) interactions with the protease to improve potency against MDR protease variants, while constraining inhibitors within the substrate envelope to avoid resistance. ${ }^{23}$ We previously used the substrate envelope-guided design strategy to develop a series of highly potent DRV analogues that maintained excellent antiviral potencies against a panel of clinically relevant MDR HIV-1 strains. ${ }^{23}$ The X-ray cocrystal structures confirmed that the designed PIs optimally fill the substrate envelope and make enhanced vdW contacts and hydrogen bonding interactions with HIV-1 protease. $^{23,24}$

Among these PIs, compounds 3 and 4 (Figure 1) with the 4(hydroxymethyl)benzene P2' moiety were identified as promising lead compounds due to distinct polar interactions of the benzylic hydroxyl group with the protease. Cocrystal structures of PIs 3 and 4 bound to wild-type HIV-1 protease revealed that the $\mathrm{P} 2^{\prime}$ benzylic hydroxyl group is positioned close to the backbone $\mathrm{NH}$ of Asp29' and Asp30' in the S2' subsite. The hydroxyl group makes a direct hydrogen bond only with the backbone $\mathrm{NH}$ of Asp30', which is slightly closer than the NH of Asp29' (Figure S1). ${ }^{23,24}$ We reasoned that introduction of a small hydrophobic group such as a methyl at the benzylic position could shift the resulting secondary hydroxyl group closer to the backbone $\mathrm{NH}$ of Asp29', allowing polar interactions with both residues, as well as additional vdW contacts in the S2' subsite. Similarly, a hydroxymethyl group at the benzylic position could serve the same purpose, with the primary hydroxyl group making additional polar interactions in the S2' subsite of HIV-1 protease (Figure 1). Optimal polar interactions of the $\mathrm{P} 2$ ' moiety with the backbone $\mathrm{NH}$ of Asp29' and Asp30' could potentially mimic the strong hydrogen bonding interaction of the P2 bis-THF moiety, further improving potency against MDR HIV-1 variants. Previous efforts to identify an optimal $\mathrm{P} 2$ ' moiety have only been partially successful, and none of the reported $\mathrm{P} 2{ }^{\prime}$ moieties make direct hydrogen bonding interactions with the backbone atoms of both Asp29' and Asp30'. ${ }^{16,25-27}$

On the basis of insights from the structural analysis and modeling, modifications of the P2' moiety of PIs 3 and 4, in combination with variations at the $\mathrm{P} 1^{\prime}$ group, were explored to enhance inhibitor interactions in the $\mathrm{S}^{\prime}{ }^{\prime}$ and $\mathrm{S} 2^{\prime}$ subsites. Here, we describe the substrate envelope-guided design, synthesis, evaluation of biochemical and antiviral potency, and crystal structure analysis of a series of novel HIV-1 PIs. The inhibitors were designed by incorporating stereoisomers of the 4-(1-hydroxyethyl)benzene and 4-(1,2-dihydroxyethyl)benzene moieties as novel P2' ligands to enhance hydrogen bonding interactions in the S2' subsite of HIV-1 protease. Structure-activity relationship (SAR) studies identified a number of compounds with improved potency profiles compared to DRV and the parent compounds against highly drug-resistant HIV-1 strains representing the spectrum of clinically relevant MDR viruses. We also report high-resolution crystal structures of all new compounds bound to wild-type HIV-1 protease revealing key interactions of the chiral 4-(1hydroxyethyl)benzene and 4-(1,2-dihydroxyethyl)benzene moieties in the protease active site. A unique pattern of hydrogen bonding interactions was observed for compounds incorporating the $(R)$-4-(1,2-dihydroxyethyl)benzene as $\mathrm{P} 2$ ' ligand, where both $\mathrm{P} 2$ and $\mathrm{P} 2{ }^{\prime}$ moieties make direct hydrogen bonds with the backbone $\mathrm{NH}$ of residues Asp29/29' and Asp30/30'.

\section{CHEMISTRY}

The synthesis of HIV-1 PIs with the (S)- and (R)-(1hydroxyethyl)benzene moieties at the $\mathrm{P} 2$ ' position is outlined 
in Scheme 1. We envisioned generating both stereoisomers of the hydroxyethyl group at the $\mathrm{P}^{\prime}$ moiety from the

Scheme 1. Synthesis of Protease Inhibitors Incorporating (S)- and (R)-4-(1-Hydroxyethyl)benzene as P2' Ligands ${ }^{a}$
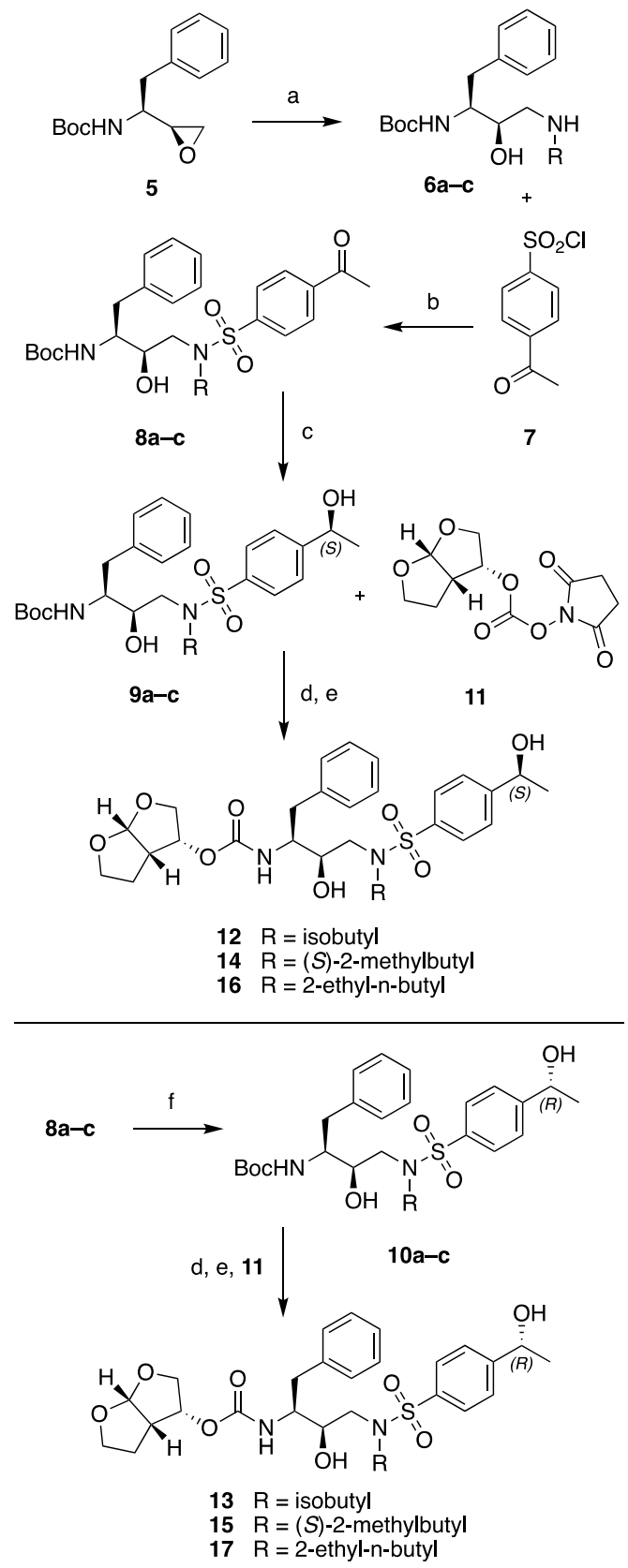

${ }^{a}$ Reagents and conditions: (a) $\mathrm{RNH}_{2}, \mathrm{EtOH}, 70{ }^{\circ} \mathrm{C}, 3 \mathrm{~h}, 79-91 \%$; (b) $\mathrm{Na}_{2} \mathrm{CO}_{3}$, EtOAc, $\mathrm{H}_{2} \mathrm{O}$, RT, 18 h, 98-100\%; (c) R-CBS-Me, $\mathrm{BH}_{3}$ THF ( $1 \mathrm{M}$ ), THF, $0{ }^{\circ} \mathrm{C}$ to RT, $3 \mathrm{~h}, 57-85 \%$; (d) TFA, $\mathrm{CH}_{2} \mathrm{Cl}_{2}, \mathrm{RT}$, $1 \mathrm{~h}$; (e) DIEA, $\mathrm{CH}_{3} \mathrm{CN}, \mathrm{RT}, 24 \mathrm{~h}, 73-91 \%$; (f) S-CBS-Me, $\mathrm{BH}_{3}-\mathrm{THF}$ (1 M), THF, $0{ }^{\circ} \mathrm{C}$ to RT, $3 \mathrm{~h}, 47-87 \%$.

corresponding 4-acetylbenzene derivatives by enantioselective reduction of the acetyl group using the Corey-Bakshi-Shibata (CBS) catalyst. ${ }^{28}$ The 4-acetylbenzenesulfonamide intermediates $\mathbf{8 a}-\mathbf{c}$ were prepared from the commercially available epoxide $\mathbf{5}$ in two steps. Ring opening of the chiral epoxide $\mathbf{5}$ with selected amines provided the amino alcohols $6 \mathrm{a}-\mathrm{c}$, which were reacted with 4 -acetylbenzenesulfonyl chloride 7 using
$\mathrm{Na}_{2} \mathrm{CO}_{3}$ as a base under biphasic conditions to afford the 4acetylbenzenesulfonamide intermediates $\mathbf{8 a - c}$ in excellent yield. Reduction of the acetyl group using $\mathrm{BH}_{3}$-THF in the presence of the chiral catalyst $(R)$-CBS-Me provided the required intermediates with the $(S)$-(1-hydroxyethyl)benzene moiety $9 a-c$ with excellent enantioselectivity. After purification by flash chromatography, the products were recrystallized from a mixture of EtOAc and hexanes to ensure chiral purity. Removal of the Boc protecting group with TFA and reaction of the resulting amine salts with the bis-THF activated carbonate 11 provided the target compounds 12, 14, and 16 with the (S)-4-(1-hydroxyethyl)benzene moiety at the $\mathrm{P} 2$ ' position. Inhibitors with the corresponding (R)-4-(1-hydroxyethyl)benzene at the $\mathrm{P} 2$ ' position were prepared similarly using the $(S)$-CBS-Me as the catalyst during the stereoselective reduction step and provided the desired inhibitors 13, 15, and 17.

The protease inhibitors with the $(R)$ - and $(S)-4-(1,2-$ dihydroxyethyl)benzene moieties at the $\mathrm{P} 2$ ' position were prepared from the corresponding styrene derivatives by Sharpless asymmetric dihydroxylation using the $\mathrm{AD}$-mix catalyst $^{29,30}$ as outlined in Scheme 2. Briefly, reactions of amino alcohols $\mathbf{6 a}-\mathbf{c}$ with 4-vinylbenzenesulfonyl chloride 18 using $\mathrm{Na}_{2} \mathrm{CO}_{3}$ as a base under biphasic conditions provided the 4-vinylbenzenesulfonamide intermediates $19 \mathbf{a}-\mathbf{c}$. The asymmetric dihydroxylation reaction using $\mathrm{AD}-\mathrm{mix}-\beta$ as a chiral catalyst proceeded smoothly and provided the required intermediates with the (R)-4-(1,2-dihydroxyethyl)benzene moiety $20 a-c$. In all cases the $(S)$-epimer was not detected by ${ }^{1} \mathrm{H}$ NMR; however, the products were recrystallized to provide enantiomerically pure intermediates $20 \mathrm{a}-\mathrm{c}$. Analogous to the compound series with the 4-(1-hydroxyethyl)benzene P2' moiety, Boc deprotection and the reaction of the resulting amine salts with the bis-THF carbonate 11 provided the target compounds 22, 24, and 26 with the (R)-4-(1,2dihydroxyethyl)benzene moiety at the $\mathrm{P} 2$ ' position. Inhibitors with the corresponding (S)-4-(1,2-dihydroxyethyl)benzene moiety at the $\mathrm{P} 2$ ' position were prepared in a similar fashion using the $\mathrm{AD}$-mix- $\alpha$ as the chiral catalyst in the asymmetric dihydroxylation reaction and provided the target inhibitors $\mathbf{2 3}$, 25 , and 27.

\section{RESULTS AND DISCUSSION}

Our goal was to improve the potency of PIs against MDR HIV1 variants by optimizing hydrogen bonding interactions in the S2' subsite of HIV-1 protease. Specifically, we explored the possibility of additional hydrogen bonding interactions between the hydroxyl group of the $\mathrm{P} 2$ ' moiety and the backbone amide $\mathrm{NH}$ of Asp29' and Asp30' on the basis of an analysis of 3- and 4-bound HIV-1 protease structures and molecular modeling. Addition of a methyl group to the hydroxymethyl substituent was expected to shift the hydroxyl group closer to the backbone $\mathrm{NH}$ of Asp29', while increasing $\mathrm{vdW}$ interactions with residues in the $\mathrm{S} 2^{\prime}$ subsite. Similarly, replacement of the hydroxymethyl group with a more polar 1,2-dihydroxyethyl was intended to enhance polar interactions; particularly the second hydroxyl group was expected to replace the water-mediated interactions between the $\mathrm{P} 2$ ' moiety and the Asp30' side chain. However, due to the free rotation of the hydroxyethyl and dihydroxyethyl groups, modeling did not provide a clear distinction which of the two stereoisomers would provide optimal polar and vdW interactions. Thus, both $(R)$ - and $(S)$-stereoisomers of 4-(1-hydroxyethyl)benzene and 
Scheme 2. Synthesis of Protease Inhibitors Incorporating $(S)$ - and (R)-4-(1,2-Dihydroxyethyl)benzene as P2' $^{\prime}$ Ligands $^{a}$

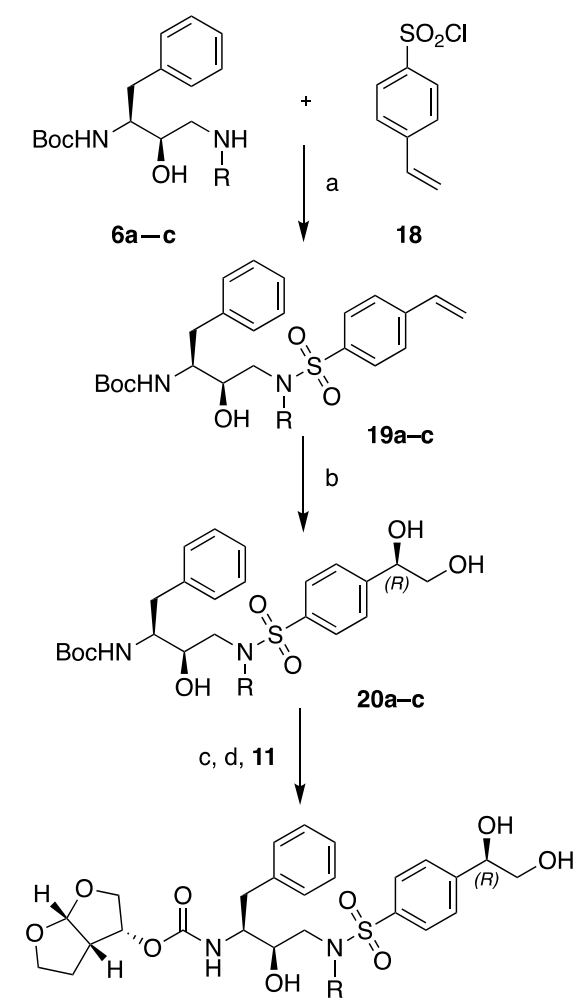

$22 \mathrm{R}=$ isobutyl

$24 \mathrm{R}=(S)$-2-methylbutyl

$26 R=2$-ethyl-n-butyl

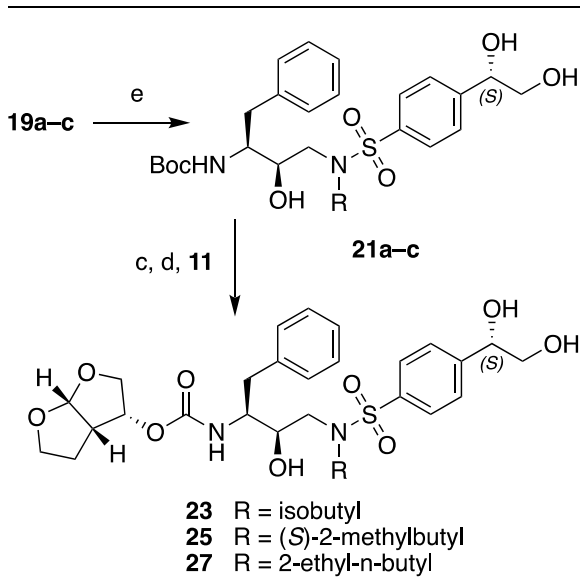

${ }^{a}$ Reagents and conditions: (a) $\mathrm{Na}_{2} \mathrm{CO}_{3}$, EtOAc, $\mathrm{H}_{2} \mathrm{O}$, RT, 18 h, 7594\%; (b) $\mathrm{AD}-$ mix $-\beta, t-\mathrm{BuOH}, \mathrm{H}_{2} \mathrm{O}, \mathrm{RT}, 4 \mathrm{~h}, 68-87 \%$; (c) TFA, $\mathrm{CH}_{2} \mathrm{Cl}_{2}$, RT, $1 \mathrm{~h}$; (d) DIEA, $\mathrm{CH}_{3} \mathrm{CN}, \mathrm{RT}, 24 \mathrm{~h}, 33-79 \%$; (e) $\mathrm{AD}-$ mix- $\alpha, t-\mathrm{BuOH}, \mathrm{H}_{2} \mathrm{O}$, RT, 4 h, $47-86 \%$.

4-(1,2-dihydroxyethyl)benzene moieties were explored as $\mathrm{P} 2^{\prime}$ ligands in combination with three $\mathrm{P} 1^{\prime}$ groups of varying size and hydrophobicity.

Enzyme Inhibition Assays. The binding affinity of HIV-1 PIs has reached a level where assessing the inhibition of wildtype protease using standard FRET-based assays is quite difficult. Accurate measurement of inhibition constants in the low $\mathrm{pM}$ range remains a challenge even with the recently reported highly sensitive fluorogenic assay. ${ }^{31}$ Due to these limitations, two drug-resistant protease variants, I84V and
I50V/A71V, were selected to assess the potency of new PIs. $\mathrm{I} 84 \mathrm{~V}$ is a common drug resistance mutation that reduces susceptibility to all FDA-approved PIs, while I50V/A71V mutations arise in response to therapy with APV- and DRVbased regimens, resulting in reduced susceptibility to these PIs. The enzyme inhibition constants $\left(K_{\mathrm{i}}\right)$ were determined against the I84V and I50V/A71V protease variants using the highly sensitive FRET assay; ${ }^{31}$ DRV was used as a control in all assays (Table 1).

DRV retained excellent potency against the I84V and I50V/ A71V protease variants $\left(K_{\mathrm{i}}=25 \mathrm{pM}\right.$ and $75 \mathrm{pM}$, respectively) compared to that reported for wild-type protease $\left(K_{\mathrm{i}}=5-16\right.$ $\mathrm{pM}){ }^{13,23,31}$ Compound 3 , which incorporates a 4(hydroxymethyl)benzene moiety as $\mathrm{P} 2$ ' ligand and (S)-2methylbutyl group at the $\mathrm{P} 1^{\prime}$ position, showed better potency against the I84V protease but was equipotent to DRV against the I50V/A71V variant. Analogue 4, with a larger 2-ethylbutyl group at the $\mathrm{P} 1^{\prime}$ position, was more active than DRV against both the $I 84 \mathrm{~V}$ and $\mathrm{I} 50 \mathrm{~V} / \mathrm{A} 71 \mathrm{~V}$ protease variants. The corresponding analogue 2 with the isobutyl $\mathrm{P}^{\prime}{ }^{\prime}$ group was previously reported to be equipotent to DRV against wild-type protease but exhibited relatively lower antiviral potency, presumably due to reduced hydrophobicity. ${ }^{13,32}$ Thus, as we have previously shown, PIs with 4-(hydroxymethyl)benzene as the $\mathrm{P} 2$ ' moiety in combination with larger, more hydrophobic (S)-2-methylbutyl and 2-ethylbutyl $\mathrm{P}^{\prime}$ groups maintained potency against drug-resistant protease variants.

Replacement of the 4-(hydroxymethyl)benzene P2' moiety of PIs 2-4 with $(S)$ - and (R)-4-(1-hydroxyethyl)benzene resulted in pairs of diastereoisomers epimeric at $\mathrm{P} 2{ }^{\prime}$. The $\mathrm{P} 2{ }^{\prime}$ hydroxyethyl analogues 12-17 showed excellent inhibitory potencies against the $184 \mathrm{~V}$ and $\mathrm{I} 50 \mathrm{~V} / \mathrm{A} 71 \mathrm{~V}$ protease variants with $K_{\mathrm{i}}$ values ranging between 20 and $132 \mathrm{pM}$. In each case, both diastereoisomers were relatively less potent than the corresponding parent hydroxymethyl compound, particularly against the $\mathrm{I} 84 \mathrm{~V}$ protease variant. However, no major difference in inhibitory potency was observed between $\mathrm{P}^{\prime}$ epimeric compounds. Only compounds with the isobutyl P1' group showed minor differences in inhibitory potencies between the $\mathrm{P} 2$ ' epimers, as diastereoisomer 12, with $(S)$ configuration of the hydroxyethyl group, was slightly more potent than the corresponding $(R)$-epimer 13 . While this work was underway, Ghosh et al. reported the synthesis of PIs 12 and 13 using a much longer reaction sequence; both compounds were tested against wild-type HIV-1 protease, and only compound $\mathbf{1 3}$ was evaluated for antiviral activity. ${ }^{33}$

Diastereoisomers 14 and 15 , with the $(S)$-2-methylbutyl P1' group, showed similar potencies against the I84V and I50V/ A71V protease variants, and both were less potent than the parent 3. Similarly, no difference in inhibitory potency was observed between diastereoisomers 16 and 17 incorporating the 2-ethylbutyl $\mathrm{P1}^{\prime}$ group. However, analogues 16 and 17 were more potent against the $\mathrm{I} 84 \mathrm{~V}$ protease $\left(K_{\mathrm{i}}=20\right.$ and 28 $\mathrm{pM}$, respectively) and exhibited overall potency profiles comparable to that of DRV. Together, these data demonstrate that minor modifications to the $\mathrm{P} 1^{\prime}$ and $\mathrm{P} 2^{\prime}$ moieties result in distinct potency profiles.

In contrast to the 4-(1-hydroxyethyl)benzene $\mathrm{P} 2$ ' series, compounds with the 4-(1,2-dihydroxyethyl)benzene P2' moiety showed clear differences in inhibitory potency between the $\mathrm{P} 2$ '-epimers. Compounds incorporating the $(R)-4-(1,2-$ dihydroxyethyl)benzene $\mathrm{P}^{\prime}$ moiety were 2-3-fold more potent than the corresponding $(S)$-epimers. Diastereoisomer 
Table 1. Protease Inhibitory Activity of PIs $12-17$ and 2227 against Drug-Resistant Variants ${ }^{a}$

\begin{tabular}{|c|c|c|c|}
\hline \multirow{2}{*}{ Inhibitor } & \multirow{2}{*}{ Structure } & \multicolumn{2}{|c|}{$K \mathrm{i}(\mathrm{nM})$} \\
\hline & & $\mathrm{I} 84 \mathrm{~V}$ & I50V/A71V \\
\hline 12 & & $0.048 \pm 0.004$ & $0.057 \pm 0.008$ \\
\hline 13 & & $0.109 \pm 0.007$ & $0.092 \pm 0.008$ \\
\hline 14 & & $0.111 \pm 0.008$ & $0.093 \pm 0.013$ \\
\hline 15 & & $0.095 \pm 0.005$ & $0.132 \pm 0.014$ \\
\hline 16 & & $0.020 \pm 0.002$ & $0.102 \pm 0.010$ \\
\hline 17 & & $0.028 \pm 0.003$ & $0.107 \pm 0.014$ \\
\hline 22 & & $0.098 \pm 0.008$ & $0.090 \pm 0.008$ \\
\hline 23 & & $0.283 \pm 0.024$ & NT \\
\hline 24 & & $0.216 \pm 0.011$ & NT \\
\hline 25 & & $0.504 \pm 0.039$ & NT \\
\hline 26 & & $0.057 \pm 0.004$ & $0.074 \pm 0.006$ \\
\hline 27 & & $0.134 \pm 0.007$ & $0.220 \pm 0.011$ \\
\hline 3 & & $0.010 \pm 0.003$ & $0.080 \pm 0.006$ \\
\hline 4 & & $0.005 \pm 0.002$ & $0.055 \pm 0.004$ \\
\hline DRV & & $0.025 \pm 0.006$ & $0.075 \pm 0.006$ \\
\hline
\end{tabular}

${ }^{a} \mathrm{NT}$ : not tested.

22, with the isobutyl group at the $P 1^{\prime}$ position and $(R)$ configuration of the dihydroxyethyl group, exhibited excellent inhibitory potency against the $184 \mathrm{~V}$ and $150 \mathrm{~V} / \mathrm{A} 71 \mathrm{~V}$ proteases, while the corresponding $(S)$-epimer 23 was about 3-fold less active against the $I 84 \mathrm{~V}$ protease. A similar trend was observed for diastereoisomers $\mathbf{2 4}$ and $\mathbf{2 5}$ incorporating the (S)-2methylbutyl $\mathrm{P1}^{\prime}$ group, though both compounds were 2 -fold less active against the $\mathrm{I} 84 \mathrm{~V}$ protease than the corresponding isobutyl $\mathrm{P} 1^{\prime}$ analogues 23 and 24. The analogue 26 incorporating the larger 2-ethylbutyl $\mathrm{P}^{\prime}$ ' group and $(R)$ configuration of the dihydroxyethyl group was the most potent in this series, with enzyme potency against the I50V/A71V protease variant comparable to that of DRV. Again, the corresponding $\mathrm{P}^{\prime}$ (S)-epimer 27 was 2-3-fold less potent against the protease variants tested. Thus, the shape of the hydrophobic group at $\mathrm{P}^{\prime}$ and the configuration of the dihydroxyethyl group at $\mathrm{P} 2$ ' affected inhibitor potency against drug-resistant protease variants.

Antiviral Assays. The potency and resistance profiles of PIs were evaluated using a cell-based antiviral assay against wild-type HIV-1 and three representative MDR variants selected from a panel of clinically relevant multi-PI resistant recombinant clones (Table 2, Table S1). ${ }^{34}$ Relative to the wild-

Table 2. Antiviral Potency of PIs 12-17 and 22-27 against WT HIV-1 and Drug-Resistant Variants ${ }^{a}$

\begin{tabular}{lcllll} 
& & \multicolumn{4}{c}{ Antiviral EC $_{50}(\mathrm{nM})(\text { fold change })^{c}$} \\
\cline { 3 - 6 } Inhibitor & cLogP $^{b}$ & WT & \multicolumn{1}{c}{ SLK19 } & VSL20 & \multicolumn{1}{c}{ KY24 } \\
$\mathbf{1 2}$ & 2.885 & 4.7 & $31(7)$ & $117(25)$ & $352(75)$ \\
$\mathbf{1 3}$ & 2.885 & 7.5 & $100(13)$ & $148(20)$ & $360(48)$ \\
$\mathbf{1 4}$ & 3.414 & 4.6 & $49(11)$ & $281(61)$ & $490(107)$ \\
$\mathbf{1 5}$ & 3.414 & 4.2 & $91(22)$ & $291(69)$ & $342(81)$ \\
$\mathbf{1 6}$ & 3.943 & 4.4 & $26(6)$ & $112(25)$ & $196(45)$ \\
$\mathbf{1 7}$ & 3.943 & 5.1 & $32(6)$ & $420(82)$ & $345(68)$ \\
$\mathbf{2 2}$ & 1.673 & 176 & $\mathrm{NT}$ & $\mathrm{NT}$ & $\mathrm{NT}$ \\
$\mathbf{2 3}$ & 1.673 & 189 & $\mathrm{NT}$ & $\mathrm{NT}$ & $\mathrm{NT}$ \\
$\mathbf{2 4}$ & 2.202 & 80 & $\mathrm{NT}$ & $\mathrm{NT}$ & $\mathrm{NT}$ \\
$\mathbf{2 5}$ & 2.202 & 92 & $\mathrm{NT}$ & $\mathrm{NT}$ & $\mathrm{NT}$ \\
$\mathbf{2 6}$ & 2.731 & 40 & $116(3)$ & $100(3)$ & $507(13)$ \\
$\mathbf{2 7}$ & 2.731 & 41 & $151(4)$ & $417(10)$ & $1154(28)$ \\
$\mathbf{3}$ & 3.105 & 5.7 & $52(9)$ & $310(54)$ & $1087(191)$ \\
$\mathbf{4}$ & 3.634 & 4.2 & $36(9)$ & $426(101)$ & $495(118)$ \\
DRV & 2.387 & 5.5 & $33(6)$ & $320(58)$ & $1157(210)$
\end{tabular}

${ }^{a} \mathrm{NT}$ : not tested. ${ }^{b} \mathrm{cLogP}$ values were calculated using ChemDraw 18. ${ }^{c}$ The multidrug-resistant HIV-1 variants SLK19, VSL20, and KY24 contain the following amino acid substitutions in HIV-1 protease compared to the WT NL4-3 strain: SLK19 (L10I, V11I, I13V, K14R, A22V, E35D, M36I, N37D, G48M, F53L, I54V, I62V, L63P, A71V, T74S, V82A, I84V, T91S, Q92K); VSL20 (L10I, K20R, L33F, E34A, E35D, M36I, N37D, K43T, M46I, G48V, I50V, I54T, I62V, L63P, A71V, I72V, V77I, V82A, I85V, I93L); KY24 (L10V, T12V, I13V, I15V, K20M, V32I, L33F, K43T, M46I, I47V, I54M, D60E, Q61N, I62V, L63P, C67Y, H69K, A71I, I72L, G73S, V77I, V82A, L89V, L90M).

type HIV-1 strain NL4-3 (with a near consensus protease sequence), the MDR variants contain 19, 20, and 24 amino acid substitutions in the protease and are named SLK19, VSL20, and KY24, respectively. All three variants show highlevel resistance and cross-resistance to multiple PIs including DRV, as determined by the Monogram Biosciences (South San Francisco, CA) PhenoSense assay. ${ }^{34}$ Accordingly, in antiviral assays, the MDR variants exhibited increasingly high-level resistance to DRV: compared to wild-type HIV-1, DRV was 6fold less potent against SLK19, 58-fold less potent against VSL20, and 210-fold less potent against KY24. Thus, the three selected MDR HIV-1 strains represent clinically relevant MDR viruses with a wide spectrum of DRV resistance.

The 4-(hydroxymethyl)benzene P2' analogues 3 and 4 were equipotent to DRV against wild-type $\mathrm{HIV}-1$ with $\mathrm{EC}_{50}$ values 
A

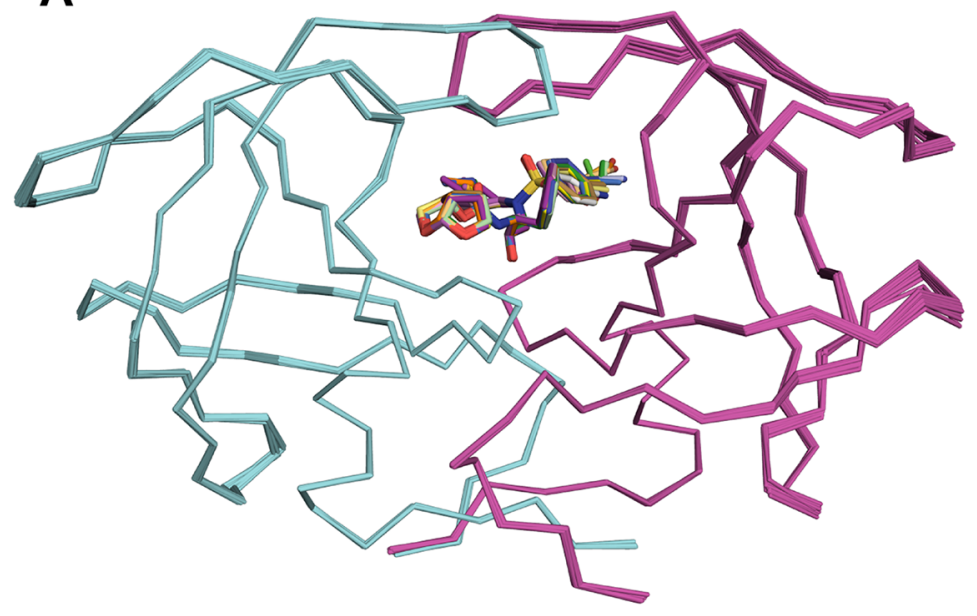

C

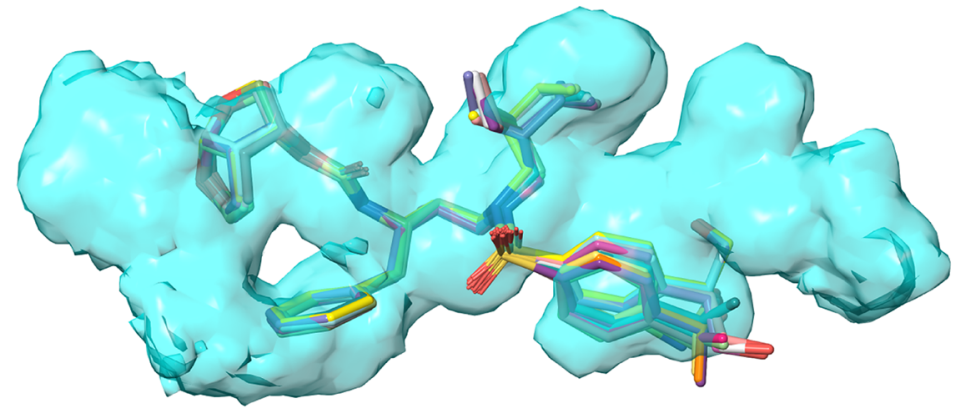

B

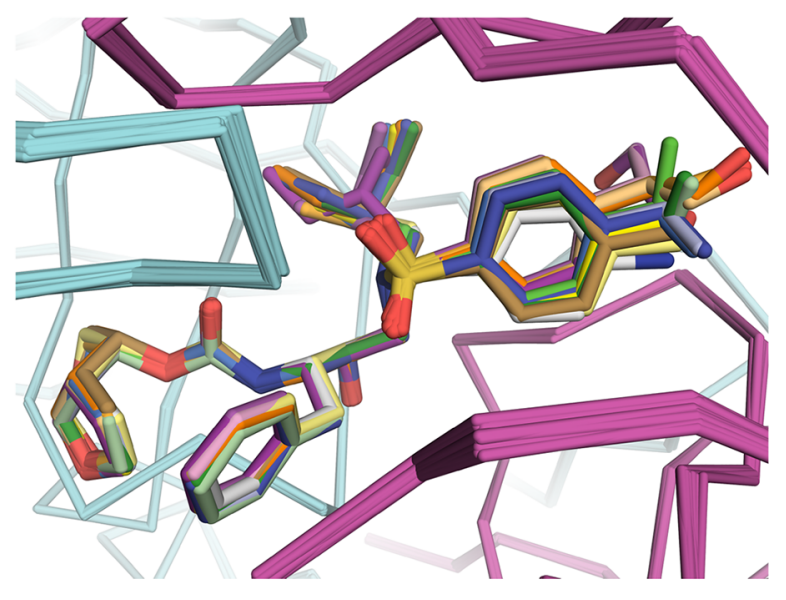

D

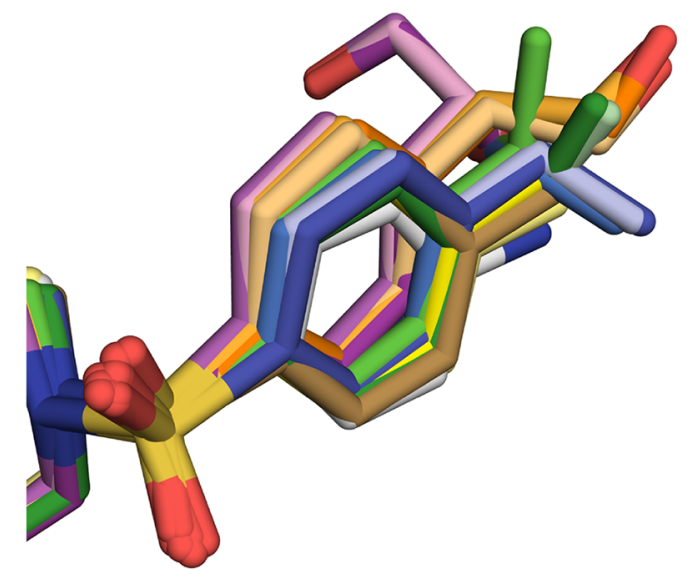

Figure 2. Comparison of binding modes of protease inhibitors with 4-(1-hydroxyethyl)benzene and 4-(1,2-dihydroxyethyl)benzene P2' moieties in the active site of wild-type HIV-1 protease. The two protease monomers are in cyan (denoted as nonprime) and magenta (denoted as prime). Superposition of protease complexes with DRV (1), parent compounds (2-4), and new analogues (12-17 and 22-27). The inhibitors are shown as sticks, and HIV-1 protease dimers are shown as ribbons. (B) Zoomed-in active site of superimposed complexes. The inhibitors bind to wild-type HIV-1 protease in similar conformations except minor variations in the S2' subsite. (C) Fit of inhibitors within the substrate envelope. The substrate envelope is in blue space filling representation, and the superimposed inhibitors are displayed as sticks. There is minimal protrusion of inhibitors outside the active site. (D) Variations in the binding mode of the inhibitors' $\mathrm{P} 2$ ' moieties.

of 5.7 and $4.2 \mathrm{nM}$, respectively. The two analogues retained potent activity against the SLK19 variant but were significantly less potent against the VSL20 variant, with $\mathrm{EC}_{50}$ values similar to that of DRV. Compared to DRV and compound 3, both of which showed similar potencies against the three MDR variants, analogue 4 retained 2 -fold better potency against the KY24 variant. The slightly improved resistance profile of compound $\mathbf{4}$ is in agreement with previous results and indicates that optimizing vdW interactions in the $S 1^{\prime}$ pocket can improve potency against MDR viruses. ${ }^{23}$

All compounds incorporating the 4-(1-hydroxyethyl)benzene $\mathrm{P} 2$ ' moieties (12-17) potently inhibited wild-type HIV-1 with $\mathrm{EC}_{50}$ values similar to that of DRV and parent compounds 3 and 4. However, the three MDR HIV-1 variants showed distinct susceptibilities to each of these compounds, depending on the $\mathrm{P} 1^{\prime}$ group and the configuration of the hydroxyethyl group at the $\mathrm{P} 2^{\prime}$ moiety. Compound 12 , with the isobutyl $\mathrm{P} 1^{\prime}$ group and the $(S)-4$-(1-hydroxyethyl)benzene $\mathrm{P} 2{ }^{\prime}$ moiety, was equipotent to DRV against SLK19 but exhibited 2-3-fold better potency against the highly resistant MDR variants VSL20 and KY24, resulting in an overall improved resistance profile. The corresponding epimer 13, incorporating the (R)-4-(1-hydroxyethyl)benzene P2' moiety, while showing a 3-fold lower potency against SLK19, retained similar potency as 12 against VSL20 and KY24. Diastereoisomers 14 and 15, with the $(S)$-2-methylbutyl $\mathrm{P}^{\prime}$ group, exhibited similar potency profiles as the corresponding analogues 12 and 13, except for a 2 -fold loss in potency against VSL20. Further improvement in overall potency profile was realized with analogue 16, incorporating a larger 2-ethylbutyl $\mathrm{P}^{\prime}$ group and the (S)-4-(1-hydroxyethyl)benzene P2' moiety, which maintained similar potency against SLK19 as DRV but demonstrated about 3- and 6-fold increase in potency against VSL20 and KY24, respectively. Moreover, compared to the parent compound 4, analogue 16 demonstrated 4- and 2-fold improved potency against VSL20 and KY24. Compared to 16, the $(R)$-epimer 17 maintained similar potency against SLK19 but exhibited lower potency against VSL20 and KY24. While all compounds with the 4-(1-hydroxyethyl)benzene as P2' ligands maintained excellent potency against MDR HIV-1 variants, each exhibited a distinct resistance profile depending 

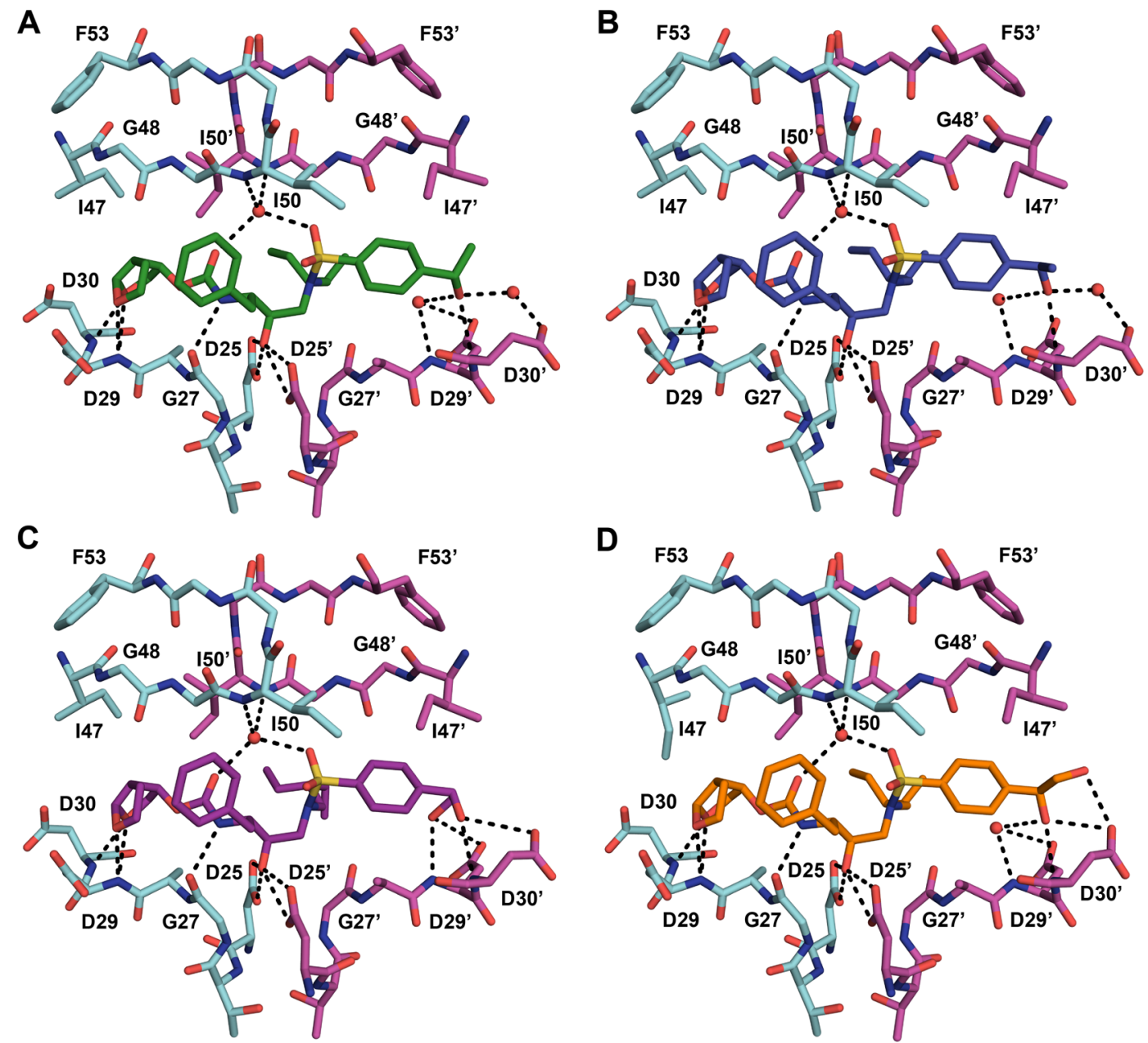

Figure 3. Crystal structures of wild-type HIV-1 protease in complex with inhibitors (A) 16, (B) 17, (C) 26, and (D) 27. Both (R)- and (S)stereoisomers of the P2' 4-(1-hydroxyethyl)benzene moiety make direct hydrogen bonding interactions with the backbone $\mathrm{NH}$ of Asp30' in the $S 2^{\prime}$ subsite $(\mathrm{A}$ and $\mathrm{B})$. The $(R)$-stereoisomer of the $\mathrm{P} 2^{\prime}$ 4-(1,2-dihydroxyethyl)benzene moiety makes hydrogen bonding interactions with the backbone NH of Asp29' and Asp30' (C). The (S)-stereoisomer of the P2' 4-(1,2-dihydroxyethyl)benzene moiety makes hydrogen bonding interactions with the backbone $\mathrm{NH}$ and side chain carboxylate group of Asp30' (D).

on the configuration of the hydroxyethyl group and size of the P1' group.

The introduction of a more polar 4-(1,2-dihydroxyethyl)benzene moiety as the $\mathrm{P} 2^{\prime}$ ligand resulted in significantly reduced potency against wild-type HIV-1, despite compounds 22-27 showing pM inhibitory activities in biochemical assays. The observed loss of potency in cellular assays is likely due to reduced hydrophobicity, as indicated by lower calculated partition coefficient $(\log \mathrm{P})$ values compared to DRV (Table 1 ). The cellular potency of HIV-1 protease inhibitors has been shown to strongly correlate with the hydrophobicity descriptor LogP, suggesting that membrane transport is a key factor affecting antiviral potency. ${ }^{35}$

The observed antiviral potencies of the 4-(1,2dihydroxyethyl)benzene containing compounds indeed correlate with their cLogP values (Figure S2). In all cases both diastereoisomers exhibited similar antiviral potencies against wild-type HIV-1. Compounds 22 and 23, incorporating the isobutyl P1' group, showed significantly lower potency than DRV. Replacement of the isobutyl $P 1^{\prime}$ group with a slightly more hydrophobic $(S)$-2-methylbutyl group, providing analogues 24 and 25, resulted in further improvement in antiviral potency. Compounds 26 and 27, incorporating a larger 2- ethylbutyl P1' group, further increased hydrophobicity and resulted in a 2 -fold improvement in potency compared to the (S)-2-methylbuty $\mathrm{P1}^{\prime}$ analogues 24 and 25 . However, both diastereoisomers 26 and 27 were 8-fold less active than DRV against wild-type HIV-1 despite 26 exhibiting similar potency in enzyme inhibition assays. Compared to DRV the P2' $(R)$ epimer 26 maintained better potency against MDR variants VSL20 and KY24 and exhibited much lower fold potency losses. The corresponding $(S)$-epimer 27, though less active against SLK19, showed similar potency as DRV against VSL20 and KY24. Thus, the combination of a more hydrophobic 2ethylbutyl P1' group and the (R)-4-(1,2-dihydroxyethyl)benzene P2' moiety provided compounds with improved potency profiles.

Analysis of Protease-Inhibitor Complexes. To explore molecular interactions of the chiral 4-(1-hydroxyethyl)benzene and 4-(1,2-dihydroxyethyl)benzene $\mathrm{P} 2$ ' moieties, we determined crystal structures of PIs 12-17 and 22-27 bound to wild-type HIV-1 protease of the NL4-3 strain. The cocrystal structures of PIs 2-4 were also determined with the same protease enzyme, as the previously reported cocrystal structures of PIs 3 and 4 were with the wild-type protease of the SF-2 sequence, which is slightly different from NL4-3. The 


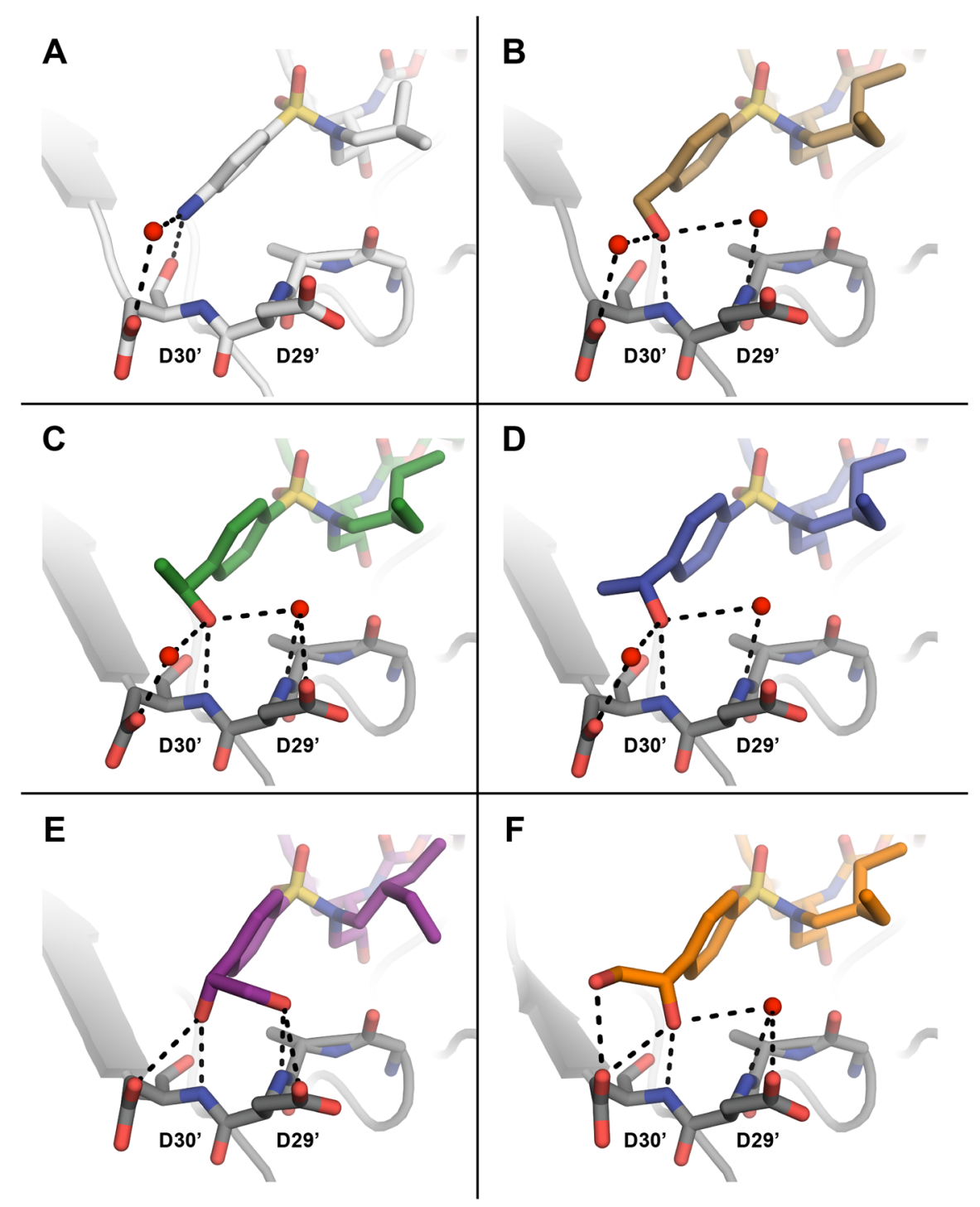

Figure 4. Comparison of binding interactions of representative PIs with modified P2' moieties in the S2' subsite of HIV-1 protease. Binding interactions of (A) DRV (PDB 6DGX), (B) parent compound 4 (PDB 6OXQ) with the 4-(hydroxymethyl)benzene P2' moiety, (C) inhibitor 16 with $(S)$-4-(1-hydroxyethyl)benzene P2' moiety, $(D)$ inhibitor 17 with the $(R)$-configuration of the P2' moiety, $(\mathrm{E})$ inhibitor 26 with $(R)$-4-(1,2dihydroxyethyl)benzene $\mathrm{P}^{\prime}$ moiety, and $(\mathrm{F})$ inhibitor 27 with the $(S)$-configuration of the $\mathrm{P}^{\prime}$ moiety.

two variants differ by four amino acids, which caused minor structural differences at the distal loops, but the active sites were nearly identical, including inhibitor binding and crystallographic waters. The crystallographic data collection and refinement statistics are summarized in Table S2. All 15 high-resolution (1.86-2.03 $\AA$ ) cocrystal structures were solved in the same $P 2{ }_{1} 2_{1} 2_{1}$ space group with one protease homodimer in the asymmetric unit, and only one orientation of the bound inhibitor in the protease active site, which was crucial for direct comparison and analysis.

The overall binding conformations of all PIs incorporating the 4-(hydroxymethyl)benzene (2-4), 4-(1-hydroxyethyl)benzene (12-17), and 4-(1,2-dihydroxyethyl)benzene (2227) $\mathrm{P} 2^{\prime}$ moieties are similar to that of DRV (Figure $2 \mathrm{~A}$ ). However, clear differences in contacts were observed in the binding of the $\mathrm{P} 2$ ' moieties depending on the substituent at the 4-position of the benzene ring and the configuration of the hydroxyl group (Figure 2B, 2D). Compared to DRV, all PIs with modified $\mathrm{P} 2$ ' ligands maintain similar hydrogen bonding interactions with the protease, except in the S2' subsite
(Figures 3 and 4). The cocrystal structures of PIs 2-4 in complex with protease showed minor changes in the conformation of the 4-(hydroxymethyl)benzene moiety compared to the 4-aminobenzene of DRV in the S2' subsite (Figure S3). In the DRV-bound protease structure, the amino group of the 4-aminobenzene $\mathrm{P}^{\prime}$ moiety is involved in hydrogen bonding interactions with the main chain carbonyl of Asp30' and water-mediated interactions with the side-chain carboxylate of Asp30' (Figure S1). The primary hydroxyl group of the 4-(hydroxymethyl)benzene P2' moiety in compounds 2-4 is oriented toward the Asp29' and Asp30' backbone and makes a direct hydrogen bond with the backbone $\mathrm{NH}$ of Asp30'. Moreover, the hydroxyl group interacts with the backbone $\mathrm{NH}$ of Asp29' and the side chain of Asp30' through water-mediated hydrogen bonds. This network of hydrogen bonding interactions in the S2' subsite likely underlies the improved potency of compounds 2-4 compared to DRV (Figure S1).

The PIs 12-17 with the 4-(1-hydroxyethyl)benzene moiety at the $\mathrm{P} 2$ ' position were designed to better position the 

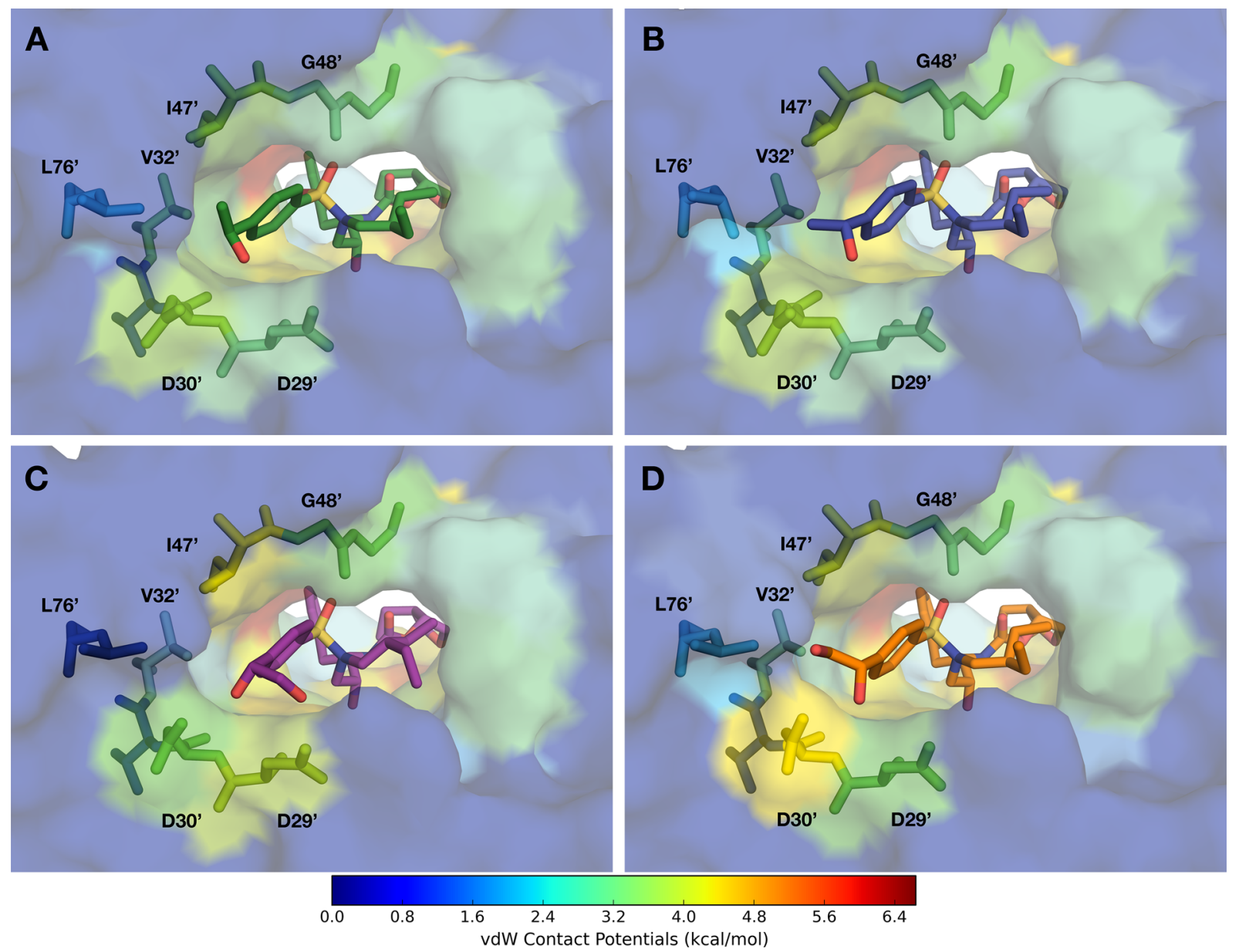

Figure 5. Packing of inhibitors (A) 16, (B) 17, (C) 26, and (D) 27 in the S2' subsite of HIV-1 protease. The protease residues are colored blue to red for increasing van der Waals ( $\mathrm{vdW}$ ) contact potentials with the inhibitor mapped onto the surface of cocrystal structures. Inhibitors and key residues are shown as sticks.

hydroxyl group between the backbone $\mathrm{NH}$ of Asp29' and Asp30'. In addition, the methyl group was expected to make $\mathrm{vdW}$ interactions with the hydrophobic residues around the S2' subsite. Similar to the parent compounds, PIs 12-17 fit well within the substrate envelope (Figure $2 \mathrm{C}$ ). For both the $(S)$ - and (R)-4-(1-hydroxyethyl)benzene $\mathrm{P} 2$ ' moieties only a portion of the hydroxyethyl substituent protrudes outside the envelope. The structures of PIs 12, 14, and 16 bound to protease superimpose very well with the corresponding parent compound structures with only subtle changes in the position and orientation of the (S)-4-(1-hydroxyethyl)benzene $\mathrm{P2}^{\prime}$ moiety. The differences in the conformation of the $\mathrm{P} 2$ ' moiety are more evident for PIs 13, 15, and 17 incorporating the $(R)$ 4-(1-hydroxyethyl)benzene, which is shifted upward toward the Gly48 backbone with a slight change in the orientation of the benzene ring compared to the position in the corresponding epimers, likely to maintain polar interactions between the hydroxyl group and the backbone $\mathrm{NH}$ of Asp30' (Figure S3).

Despite clear differences in the overall binding conformations of $(S)$ - and (R)-4-(1-hydroxyethyl)benzene P2' moieties, the secondary hydroxyl group is oriented in the same direction of the Asp29' and Asp30' backbone (Figure 4). Instead, the orientation of the methyl group is altered. As a result, regardless of the configuration of the hydroxyl group, the PIs incorporating the 4-(1-hydroxyethyl)benzene moiety (12-17) make identical direct and water-mediated hydrogen bonding interactions in the protease active site as the parent compounds 2-4 (Figure 4). In both configurations, the hydroxyl group is positioned between the backbone $\mathrm{NH}$ of Asp29' and Asp30'. However, in all structures the hydroxyl group makes a direct hydrogen bond only with the backbone $\mathrm{NH}$ of Asp30', which is closer (3.0-3.2 $\AA$ ) than the $\mathrm{NH}$ of Asp29' (3.6-3.8 $\AA$ ). The distance between the hydroxyl group and the backbone $\mathrm{NH}$ of Asp30' is slightly shorter (3.0-3.1 $\AA$ ) for compounds with the (S)-4-(1-hydroxyethyl)benzene P2' moiety than the corresponding $(R)$-epimers $(3.2 \AA)$ (Table S3). The hydroxyl group also interacts with the side chain of Asp $30^{\prime}$, mostly through water-mediated hydrogen bonds but directly in the case of compound 14. In the 14-protease complex structure the side chain of Asp $30^{\prime}$ is shifted toward the P2' moiety, resulting in a strong, direct hydrogen bond between the hydroxyl and carboxylate groups. Moreover, the hydroxyl group makes water-mediated interactions with the backbone NH of Asp29', which are not observed in the DRVprotease complex. Thus, the hydroxyl group at the $\mathrm{P} 2^{\prime}$ moiety is involved in a network of direct and water-mediated interactions in the protease active site (Figure 4).

Cocrystal structures were analyzed for vdW contacts, and compounds with the modified P2' moieties showed enhanced $\mathrm{vdW}$ interactions with protease residues in the $\mathrm{S2}^{\prime}$ subsite compared to the corresponding parent PIs 2-4 (Figure 5). To 
evaluate the changes in vdW interactions, total vdW energies per residue were calculated for each protease-inhibitor complex and the corresponding values for parent compound subtracted (Figure S5). The additional methyl group is oriented toward Ile47 in complexes with PIs 12, 14, and 16 incorporating the (S)-4-(1-hydroxyethyl)benzene P2' moiety and toward Val32 and Leu76 in the corresponding $(R)$-epimers 13, 15, and 17. Compounds with the same $\mathrm{P} 1^{\prime}$ group show minor differences in $\mathrm{vdW}$ interactions with residues in the $\mathrm{S} 2^{\prime}$ subsite depending on the configuration of the $\mathrm{P} 2^{\prime}$ hydroxyl group. The methyl group of analogue $\mathbf{1 2}$ with the $(S)$-configuration of the hydroxyl group makes additional vdW interactions with the methylene portion of the Asp $30^{\prime}$ side chain compared to the parent compound 2. Surprisingly, there is no increase in vdW contacts with Ile47 even though the methyl group of compound $\mathbf{1 2}$ is oriented toward this residue. The methyl group of the $\mathrm{P} 2^{\prime}(R)$-epimer 13 forms vdW contacts with Ile47 and Leu76. The corresponding analogues with the $(S)-2$ methylbutyl and 2-ethylbutyl $\mathrm{P}^{\prime}$ groups showed largely similar interactions as observed for $\mathbf{1 2}$ and $\mathbf{1 3}$, respectively, but a slight shift in the benzene ring caused minor differences in the vdW contacts. As previously shown for parent compounds 3 and 4, larger (S)-2-methylbutyl and 2-ethylbutyl $\mathrm{P}^{\prime}$ groups result in increased vdW contacts in the $S 1^{\prime}$ subsite, compared to the corresponding isobutyl group. Compounds with the same $\mathrm{P}^{\prime}$ group show similar vdW contacts in the $\mathrm{S}^{\prime}$ subsite. Thus, enhanced vdW interaction of PIs $\mathbf{1 2 - 1 7}$ in the S2' subsite result from the additional methyl group and altered position of the modified P2' moiety.

While compounds with the $(S)$ - and (R)-4-(1hydroxyethyl)benzene $\mathrm{P} 2$ ' moieties show minor changes in vdW contacts in the $S 2^{\prime}$ subsite, both diastereoisomers make identical hydrogen bonding interactions with the protease because the orientation of the hydroxyl group is similar in both configurations. The largely similar overall binding interactions of $\mathrm{P} 2^{\prime}$ epimeric compounds correlate with the similar enzyme inhibitory potencies observed between diastereoisomers. PIs with the (S)-4-(1-hydroxyethyl)benzene P2' moiety showed improved antiviral potency against MDR variants likely due to stronger polar interactions with the backbone atoms without relying on contacts with side chains that could mutate to cause resistance. Overall, the cocrystal structures provided insights into the binding of these new PIs with modified P2' moieties, revealing the structural basis for the observed inhibitory potencies.

The cocrystal structures of PIs 22-27, incorporating the 4(1,2-dihydroxyethyl)benzene in complex with protease, revealed a larger shift in the position of the $\mathrm{P} 2^{\prime}$ moiety compared to DRV (Figure S3). The benzene ring is moved toward the flaps, likely to accommodate the larger substituent at the 4-position. With the $(R)$-configuration of the dihydroxyethyl group, the primary hydroxyl group in PIs 22, 24, and 26 is oriented toward the Asp29' backbone and the $S 3^{\prime}$ subsite. As a result, these PIs fit very well within the substrate envelope (Figure 2C). In contrast, the primary hydroxyl group in the corresponding $(S)$-epimer compounds $\mathbf{2 3 , 2 5}$, and $\mathbf{2 7}$ is oriented in the opposite direction, toward the Asp30' and Leu76 side chains, and lies largely outside the substrate envelope. The cocrystal structures of PIs 22-27 also showed subtle variations in the binding of the secondary hydroxyl group of the $(R)$ - and $(S)$-4-(1,2-dihydroxyethyl)benzene P2' moieties. Despite differences in the binding of the dihydroxyethyl stereoisomers, similar conformations of the benzene ring were observed for both (R)- and (S)-4-(1,2-dihydroxyethyl)benzene $\mathrm{P} 2$ ' moieties.

The hydrogen bonding patterns of compounds incorporating the 4-(1,2-dihydroxyethyl)benzene as P2' ligands varied considerably depending on the configuration of the secondary hydroxyl group (Figure 4). In the cocrystal structures of PIs 22,24 , and 26 with the $(R)$-configuration of the dihydroxyethyl group, the secondary hydroxyl group makes a strong, direct hydrogen bond with the backbone $\mathrm{NH}$ of Asp30'. Another weaker but direct hydrogen bond connects the secondary hydroxyl group with the side chain carboxylate of Asp30', replacing the water-mediated interactions observed for compounds with the 4-(hydroxymethyl)- and 4-(1-hydroxyethyl)-benzene $\mathrm{P} 2$ ' moieties. The primary hydroxyl group of the $(R)$-dihydroxyethyl moiety is oriented toward the protease backbone and forms a direct hydrogen bond with the backbone $\mathrm{NH}$ of Asp29', displacing a water molecule observed in the parent compound structures (Figure S4). The primary hydroxyl group is also involved in weaker $(3.3-3.5 \AA)$, direct hydrogen bonding interactions with the side chain carboxylate of Asp29'. The unique pattern of polar interactions of the $(R)$ dihydroxyethyl group in the S2' subsite, particularly involving the backbone $\mathrm{NH}$ of Asp29' and Asp30', mimics the interactions of the bis-THF moiety in the $\mathrm{S} 2$ subsite.

The cocrystal structures of PIs $\mathbf{2 3}, \mathbf{2 5}$, and 27 with the $(S)$ configuration of the $\mathrm{P} 2$ ' dihydroxyethyl group also revealed a unique network of hydrogen bonds between the hydroxyl groups and the protease. The secondary hydroxyl group forms two direct hydrogen bonds, one with the backbone $\mathrm{NH}$ of Asp30' and another with the side chain carboxylate of the same residue. The secondary hydroxyl group is also positioned close to the backbone NH of Asp29' (3.5-3.6 $\AA$ ) and makes watermediated interactions with both the backbone $\mathrm{NH}$ and side chain carboxylate of this residue. The primary hydroxyl group is oriented toward the side chain of Asp30' and is involved in a direct hydrogen bonding interaction with the carboxyl group, replacing the water molecule observed in complexes with compounds incorporating the 4-(hydroxymethyl)- and 4-(1hydroxyethyl)-benzene $\mathrm{P} 2$ ' moieties. In this orientation, the dihydroxyethyl group forms an additional direct hydrogen bond with the protease replacing a water-mediated interaction.

In addition, PIs 22-27, incorporating the 4-(1,2dihydroxyethyl)benzene moieties as $\mathrm{P} 2$ ' ligands, form enhanced vdW contacts with the protease compared to the corresponding parent compounds 2-4. The altered position of the $\mathrm{P} 2^{\prime}$ moiety places the benzene ring closer to Gly $48^{\prime}$ in the flaps, resulting in an overall increase in vdW contacts for all PIs in this series. Minor changes in $\mathrm{vdW}$ interactions were observed between $\mathrm{P} 2$ ' epimeric compounds, with additional subtle variations resulting from changes at the $\mathrm{P} 1^{\prime}$ position (Figure S5). In general, compounds with the $(R)$-configuration of the modified P2' moiety (22, 24, and 26) make enhanced vdW interactions with Asp29', Pro81, and residues $47^{\prime}-50^{\prime}$ in the flap region but slightly reduced interactions with Val32 and Ile84 (Figure 5). The corresponding $(S)$-epimers $(\mathbf{2 3}, \mathbf{2 5}$, and 27) formed more vdW contacts with a different set of residues around the active site, including Asp30', Lys45', Ile47, and Leu76', and weaker contacts with Asp30 and Ile50. However, few exceptions to these general trends were observed for compounds $\mathbf{2 4}$ and $\mathbf{2 5}$ that incorporate the $(S)$-2-methylbutyl group at the $\mathrm{P} 1^{\prime}$ position, likely due to the asymmetric shape of the $\mathrm{P} 1^{\prime}$ group (Figure S5). Overall, for PIs incorporating the 4(1,2-dihydroxyethyl)benzene $\mathrm{P} 2$ ' moieties, the increase in vdW 
interactions with specific protease residues mainly depends on the configuration of the dihydroxyethyl group.

The cocrystal structures of PIs with the 4-(1,2dihydroxyethyl)benzene $\mathrm{P} 2$ ' moieties revealed unique hydrogen bonding patterns and vdW contacts that vary significantly, depending on the configuration of the modified $\mathrm{P}^{\prime}$ moiety. The improved potency profiles of PIs with the $(R)-4-(1,2-$ dihydroxyethyl)benzene $\mathrm{P}^{\prime}$ moiety compared to the corresponding $(S)$-epimers likely result from enhanced backbone interactions with residues Asp29' and Asp30', as well as increased vdW contacts with the side chains of Asp29' and residues in the flap region. Notably, these PIs also fit very well in the substrate envelope. Compound 26, with the 2-ethylbutyl P1' group, is a promising lead for exploring further modifications, particularly in combination with more hydrophobic P1 and P2 groups, to further improve potency against MDR variants.

\section{CONCLUSIONS}

New HIV-1 protease inhibitors were designed by incorporating stereoisomers of the 4-(1-hydroxyethyl)benzene and 4-(1,2dihydroxyethyl)benzene moieties as $\mathrm{P} 2$ ' ligands to enhance hydrogen bonding interactions in the $\mathrm{S}^{\prime}$ ' subsite. Compounds with the polar dihydroxyethyl group at the $\mathrm{P} 2$ ' moiety were generally less potent than DRV while inhibitors with the hydroxyethyl group exhibited improved antiviral potency against MDR variants. Crystal structures of protease-inhibitor complexes show that all PIs make enhanced hydrogen bonding and vdW interactions with the protease. The reduced cellular potency of PIs with the dihydroxyethyl group is likely due to their relatively low hydrophobicity, which can be counterbalanced with increased hydrophobicity at other positions such as P1. Overall, the PI potency profile was determined by the polar substituent at the 4-position of the $\mathrm{P} 2$ ' benzene ring, the configuration of the secondary hydroxyl group, and the size of the P1' group. Exploration of both stereoisomers of the P2' moiety revealed unique polar and vdW interactions, including a network of direct and water-mediated hydrogen bonding with the backbone and side chain atoms of Asp29' and Asp30'. Notably, PIs with the (R)-4-(1,2-dihydroxyethyl)benzene moiety make hydrogen bonding interactions with the backbone $\mathrm{NH}$ of Asp29' and Asp30' in the S2' subsite, mimicking the polar interactions of the P2 bis-THF moiety, and show improved potency and resistance profiles compared to the corresponding $(S)$-epimers. In general, compounds that make increased hydrogen bonding interactions with the backbone and vdW contacts with invariant residues and fit better within the substrate envelope maintain better potency against highly resistant MDR HIV-1 strains. These SAR data and structural insights may allow further optimization of these promising inhibitors.

\section{EXPERIMENTAL SECTION}

General. All reactions were performed in oven-dried roundbottom flasks fitted with rubber septa under argon atmosphere unless otherwise noted. All reagents and solvents, including anhydrous solvents, were purchased from commercial sources and used as received. Flash column chromatography was performed on an automated Teledyne ISCO CombiFlash Rf+ system equipped with a UV-vis detector using disposable Redisep Gold high performance silica gel columns or was performed manually using silica gel (230400 mesh, EMD Millipore). Thin-layer chromatography (TLC) was performed using silica gel $\left(60 \mathrm{~F}_{254}\right)$ coated aluminum plates (EMD Millipore), and spots were visualized by exposure to ultraviolet light
(UV), exposure to iodine adsorbed on silica gel, and/or staining with alcohol solutions of phosphomolybdic acid (PMA) and ninhydrin followed by brief heating. ${ }^{1} \mathrm{H}$ NMR and ${ }^{13} \mathrm{C}$ NMR spectra were acquired on Varian Mercury $400 \mathrm{MHz}$ and Bruker Avance III HD 500 $\mathrm{MHz}$ NMR instruments. Chemical shifts are reported in $\mathrm{ppm}(\delta$ scale) with the residual solvent signal used as reference, and coupling constant $(J)$ values are reported in hertz $(\mathrm{Hz})$. Data are presented as follows: chemical shift, multiplicity $(\mathrm{s}=$ singlet, $\mathrm{d}=$ doublet, $\mathrm{dd}=$ doublet of doublet, $\mathrm{dt}=$ doublet of triplet, $\mathrm{t}=$ triplet, $\mathrm{m}=$ multiplet, $\mathrm{br}$ $\mathrm{s}=$ broad singlet), coupling constant in $\mathrm{Hz}$, and integration. Highresolution mass spectra (HRMS) were recorded on a Thermo Scientific Orbitrap Velos Pro mass spectrometer coupled with a Thermo Scientific Accela 1250 UPLC and an autosampler using electrospray ionization (ESI) in the positive mode. The purity of final compounds was determined by analytical HPLC and was found to be $\geq 95 \%$ pure. HPLC was performed on a Agilent 1200 system equipped with a multiple wavelength detector and a manual injector under the following conditions: column, Phenomenex Hypersil-BDS-5u-C18 (5 $\mu \mathrm{m}, 4.6 \mathrm{~mm} \times 250 \mathrm{~mm}, 130 \AA$ ) ; solvent $\mathrm{A}, \mathrm{H}_{2} \mathrm{O}$ containing $0.1 \%$ trifluoroacetic acid (TFA); solvent $\mathrm{B}, \mathrm{CH}_{3} \mathrm{CN}$ containing $0.1 \%$ TFA; gradient, $20 \%$ B to $100 \%$ B over 15 min followed by $100 \%$ B over 5 min; injection volume, $20 \mu \mathrm{L}$; flow rate, $1 \mathrm{~mL} / \mathrm{min}$. The wavelengths of detection were $254 \mathrm{~nm}$ and $280 \mathrm{~nm}$. Retention times and purity data for each target compound are provided in the Experimental Section.

Synthesis of Protease Inhibitors. tert-Butyl ((2S,3R)-3Hydroxy-4-((4-((S)-1-hydroxyethyl)-N-isobutylphenyl)sulfonamido)-1-phenylbutan-2-yl)carbamate (9a). A solution of tert-butyl $((2 S, 3 R)-4$-((4-acetyl- $N$-isobutylphenyl)sulfonamido)-3-hydroxy-1-phenylbutan-2-yl)carbamate $8 \mathrm{a}(1.00 \mathrm{~g}, 1.93 \mathrm{mmol})$ in anhydrous tetrahydrofuran $(40 \mathrm{~mL})$ was cooled to $0{ }^{\circ} \mathrm{C}$, and the (R)-2-methyl-CBS-oxazaborolidine $(1.07 \mathrm{~g}, 3.86 \mathrm{mmol})$ catalyst was added. After stirring the reaction mixture for $15 \mathrm{~min}$, borane solution (1 $\mathrm{M}$ in THF) $(2.90 \mathrm{~mL}, 2.90 \mathrm{mmol})$ was added dropwise over an hour. Stirring was continued at $0{ }^{\circ} \mathrm{C}$ until the reaction was complete, as indicated by TLC. The reaction was quenched with an acetone/ methanol mixture $(1: 1,20 \mathrm{~mL})$ and the solvent was removed under reduced pressure. The crude product was purified by automated flash chromatography using a silica gel column (RediSep Gold, $40 \mathrm{~g}$, gradient elution with $0-100 \%$ EtOAc/hexanes), to give compound 9a as a white solid. Recrystallization from a mixture of ethyl acetate/ hexanes (1:1) provided a white solid $(0.77 \mathrm{~g}, 77 \%) .{ }^{1} \mathrm{H}$ NMR (500 $\left.\mathrm{MHz}, \mathrm{CDCl}_{3}\right) \delta 7.74(\mathrm{~d}, J=8.4 \mathrm{~Hz}, 2 \mathrm{H}), 7.51(\mathrm{~d}, J=8.3 \mathrm{~Hz}, 2 \mathrm{H})$, 7.31-7.28 (m, $2 \mathrm{H}), 7.25-7.20(\mathrm{~m}, 3 \mathrm{H}), 5.00-4.95(\mathrm{~m}, 1 \mathrm{H}), 4.63$ (d, $J=7.5 \mathrm{~Hz}, 1 \mathrm{H}), 3.92(\mathrm{~s}, 1 \mathrm{H}), 3.82-3.71(\mathrm{~m}, 2 \mathrm{H}), 3.13-3.05$ $(\mathrm{m}, 2 \mathrm{H}), 3.02-2.80(\mathrm{~m}, 4 \mathrm{H}), 2.02(\mathrm{~d}, J=3.5 \mathrm{~Hz}, 1 \mathrm{H}), 1.89-1.81$ $(\mathrm{m}, 1 \mathrm{H}), 1.51(\mathrm{~d}, J=6.5 \mathrm{~Hz}, 3 \mathrm{H}), 1.34(\mathrm{~s}, 9 \mathrm{H}), 0.91(\mathrm{~d}, J=6.5 \mathrm{~Hz}$, $3 \mathrm{H}), 0.87(\mathrm{~d}, J=7.0 \mathrm{~Hz}, 3 \mathrm{H}) \mathrm{ppm} .{ }^{13} \mathrm{C} \mathrm{NMR}\left(125 \mathrm{MHz} \mathrm{CDCl}_{3}\right) \delta$ $156.20,151.19,137.93,137.24,129.67,128.60,127.72,126.57$, $126.22,79.87,72.91,69.72,58.76,54.84,53.81,35.58,28.37,27.30$, 25.54, 20.23, $19.99 \mathrm{ppm}$. HRMS (ESI) $\mathrm{m} / z:[\mathrm{M}+\mathrm{H}]^{+}$calcd for $\mathrm{C}_{27} \mathrm{H}_{41} \mathrm{~N}_{2} \mathrm{O}_{6} \mathrm{~S}$, 521.2680; found 521.2676.

tert-Butyl ((2S,3R)-3-Hydroxy-4-((4-)((S)-1-hydroxyethyl)-N-((S)-2methylbutyl)phenyl)sulfonamido)-1-phenylbutan-2-yl)carbamate (9b). The same procedure was used as described above for compound 9a. Compound $8 \mathrm{~b}(1.00 \mathrm{~g}, 1.88 \mathrm{mmol})$ was treated with $(R)-2$ methyl-CBS-oxazaborolidine $(1.04 \mathrm{~g}, 3.75 \mathrm{mmol})$ and borane solution ( $1 \mathrm{M}$ in THF) ( $2.82 \mathrm{~mL}, 2.82 \mathrm{mmol}$ ) to give compound $9 \mathbf{b}$ as a white solid (yield after recrystallization: $0.57 \mathrm{~g}, 57 \%) .{ }^{1} \mathrm{H}$ NMR $(500 \mathrm{MHz}$, $\left.\mathrm{CDCl}_{3}\right) \delta 7.74(\mathrm{~d}, J=8.4 \mathrm{~Hz}, 2 \mathrm{H}), 7.51(\mathrm{~d}, J=8.3 \mathrm{~Hz}, 2 \mathrm{H}), 7.31-$ $7.28(\mathrm{~m}, 2 \mathrm{H}), 7.25-7.20(\mathrm{~m}, 3 \mathrm{H}), 5.00-4.95(\mathrm{~m}, 1 \mathrm{H}), 4.61(\mathrm{~d}, J=$ $6.5 \mathrm{~Hz}, 1 \mathrm{H}), 3.87(\mathrm{~s}, 1 \mathrm{H}), 3.80-3.71(\mathrm{~m}, 2 \mathrm{H}), 3.13-2.89(\mathrm{~m}, 5 \mathrm{H})$, $2.82(\mathrm{dd}, J=13.0,7.0 \mathrm{~Hz}, 1 \mathrm{H}), 2.00(\mathrm{~d}, J=3.7 \mathrm{~Hz}, 1 \mathrm{H}), 1.64-1.58$ $(\mathrm{m}, 1 \mathrm{H}), 1.51(\mathrm{~d}, J=6.5 \mathrm{~Hz}, 3 \mathrm{H}), 1.50-1.44(\mathrm{~m}, 1 \mathrm{H}$, overlapping $)$, $1.34(\mathrm{~s}, 9 \mathrm{H}), 1.11-1.02(\mathrm{~m}, 1 \mathrm{H}), 0.86-0.83(\mathrm{~m}, 6 \mathrm{H}) \mathrm{ppm} .{ }^{13} \mathrm{C}$ NMR $\left(125 \mathrm{MHz}, \mathrm{CDCl}_{3}\right) \delta 156.18,151.11,137.85,137.26,129.72$, $128.64,127.78,126.61,126.22,79.88,72.83,69.80,57.39,54.74$, $53.80,35.59,33.50,28.40,26.56,25.58,17.02,11.17 \mathrm{ppm}$. HRMS (ESI) $m / z:[\mathrm{M}+\mathrm{H}]^{+}$calcd for $\mathrm{C}_{28} \mathrm{H}_{43} \mathrm{~N}_{2} \mathrm{O}_{6} \mathrm{~S}, 535.2836$; found 535.2832 . 
tert-Butyl ((2S,3R)-4-((N-(2-Ethylbutyl)-4-((S)-1-hydroxyethyl)phenyl)sulfonamido)-3-hydroxy-1-phenylbutan-2-yl)carbamate (9c). The same procedure was used as described above for compound 9a. Compound $8 \mathrm{c}(1.00 \mathrm{~g}, 1.83 \mathrm{mmol})$ was treated with $(R)-2$ methyl-CBS-oxazaborolidine $(1.01 \mathrm{~g}, 3.66 \mathrm{mmol})$ and borane solution ( $1 \mathrm{M}$ in THF) $(2.74 \mathrm{~mL}, 2.74 \mathrm{mmol})$ to give compound $9 \mathrm{c}$ as a white solid (yield after recrystallization: $0.85 \mathrm{~g}, 85 \%) .{ }^{1} \mathrm{H}$ NMR $(500 \mathrm{MHz}$, $\left.\mathrm{CDCl}_{3}\right) \delta 7.74(\mathrm{~d}, J=8.4 \mathrm{~Hz}, 2 \mathrm{H}), 7.52(\mathrm{~d}, J=8.3 \mathrm{~Hz}, 2 \mathrm{H}), 7.31-$ $7.28(\mathrm{~m}, 2 \mathrm{H}), 7.25-7.20(\mathrm{~m}, 3 \mathrm{H}), 5.00-4.96(\mathrm{~m}, 1 \mathrm{H}), 4.58(\mathrm{~d}, J=$ $5.9 \mathrm{~Hz}, 1 \mathrm{H}), 3.92(\mathrm{~s}, 1 \mathrm{H}), 3.75(\mathrm{~m}, 2 \mathrm{H}), 3.12-2.98(\mathrm{~m}, 4 \mathrm{H})$, $2.92-2.86(\mathrm{~m}, 2 \mathrm{H}), 2.01(\mathrm{~d}, J=3.7 \mathrm{~Hz}, 1 \mathrm{H}), 1.51(\mathrm{~d}, J=6.5 \mathrm{~Hz}, 3$ $\mathrm{H}), \quad 1.49-1.37(\mathrm{~m}, 2 \mathrm{H}), 1.34(\mathrm{~s}, 9 \mathrm{H}), 1.34-1.24(\mathrm{~m}, 3 \mathrm{H}$, overlapping), $0.83-0.79(\mathrm{~m}, 6 \mathrm{H}) \mathrm{ppm} .{ }^{13} \mathrm{C}$ NMR $(125 \mathrm{MHz}$, $\left.\mathrm{CDCl}_{3}\right) \delta 156.16,151.13,137.83,137.14,129.71,128.63,127.81$, 126.60, 126.24, 79.86, 73.06, 69.80, 54.91, 54.69, 53.81, 39.09, 35.77, $28.40,25.58,23.18,22.86,10.70,10.42 \mathrm{ppm}$. HRMS (ESI) $\mathrm{m} / z$ : [M $+\mathrm{H}]^{+}$calcd for $\mathrm{C}_{29} \mathrm{H}_{45} \mathrm{~N}_{2} \mathrm{O}_{6} \mathrm{~S}$, 549.2993; found 549.2989.

tert-Butyl ((2S,3R)-3-Hydroxy-4-((4-)((R)-1-hydroxyethyl)-Nisobutylphenyl)sulfonamido)-1-phenylbutan-2-yl)carbamate (10a). The same procedure was used as described above for compound 9a. Compound $8 \mathrm{a}(1.00 \mathrm{~g}, 1.93 \mathrm{mmol})$ was treated with (S)-2-methyl-CBS-oxazaborolidine $(1.22 \mathrm{~g}, 4.40 \mathrm{mmol})$ and borane solution (1 M in THF) $(3.3 \mathrm{~mL}, 3.30 \mathrm{mmol})$ to give compound 10a as a white solid (yield after crystallization: $0.6 \mathrm{~g}, 60 \%) .{ }^{1} \mathrm{H}$ NMR (500 $\left.\mathrm{MHz}, \mathrm{CDCl}_{3}\right) \delta 7.72(\mathrm{~d}, J=8.4 \mathrm{~Hz}, 2 \mathrm{H}), 7.50(\mathrm{~d}, J=8.3 \mathrm{~Hz}, 2 \mathrm{H})$, 7.30-7.27 (m, $2 \mathrm{H}), 7.24-7.19(\mathrm{~m}, 3 \mathrm{H}), 4.98-4.93(\mathrm{~m}, 1 \mathrm{H}), 4.67$ $(\mathrm{d}, J=7.8 \mathrm{~Hz}, 1 \mathrm{H}), 3.94(\mathrm{~s}, 1 \mathrm{H}), 3.84-3.70(\mathrm{~m}, 2 \mathrm{H}), 3.12-3.04$ (m, $2 \mathrm{H}), 3.01-2.80(\mathrm{~m}, 4 \mathrm{H}), 2.35(\mathrm{~s}, 1 \mathrm{H}), 1.89-1.81(\mathrm{~m}, 1 \mathrm{H})$, $1.49(\mathrm{~d}, J=6.5 \mathrm{~Hz}, 3 \mathrm{H}), 1.33(\mathrm{~s}, 9 \mathrm{H}), 0.90(\mathrm{~d}, J=7.0 \mathrm{~Hz}, 3 \mathrm{H}), 0.86$ $(\mathrm{d}, J=6.5 \mathrm{~Hz}, 3 \mathrm{H})$ ppm. ${ }^{13} \mathrm{C}$ NMR $\left(125 \mathrm{MHz}, \mathrm{CDCl}_{3}\right) \delta 156.20$, $151.23,137.94,137.19,129.66,128.59,127.69,126.55,126.21,79.85$, 72.91, 69.67, 58.74, 54.83, 53.80, 35.57, 28.36, 27.28, 25.54, 20.22, 19.98 ppm. HRMS (ESI) $m / z$ : $[\mathrm{M}+\mathrm{H}]^{+}$calcd for $\mathrm{C}_{27} \mathrm{H}_{41} \mathrm{~N}_{2} \mathrm{O}_{6} \mathrm{~S}$, 521.2680; found 521.2682.

tert-Butyl ((2S,3R)-3-Hydroxy-4-((4-((R)-1-hydroxyethyl)-N-((S)-2methylbutyl)phenyl)sulfonamido)-1-phenylbutan-2-yl)carbamate (10b). The same procedure was used as described above for compound 9a. Compound $\mathbf{8 b}(1.00 \mathrm{~g}, 1.88 \mathrm{mmol})$ was treated with (S)-2-methyl-CBS-oxazaborolidine $(1.04 \mathrm{~g}, 3.75 \mathrm{mmol})$ and borane solution (1 M in THF) $(2.82 \mathrm{~mL}, 2.82 \mathrm{mmol})$ to give $10 \mathrm{~b}$ as a white solid (yield after recrystallization: $0.76 \mathrm{~g}, 76 \%) .{ }^{1} \mathrm{H}$ NMR $(500 \mathrm{MHz}$, $\left.\mathrm{CDCl}_{3}\right) \delta 7.74(\mathrm{~d}, J=8.4 \mathrm{~Hz}, 2 \mathrm{H}), 7.52(\mathrm{~d}, J=8.3 \mathrm{~Hz}, 2 \mathrm{H}), 7.31-$ $7.28(\mathrm{~m}, 2 \mathrm{H}), 7.25-7.20(\mathrm{~m}, 3 \mathrm{H}), 5.00-4.96(\mathrm{~m}, 1 \mathrm{H}), 4.61(\mathrm{~d}, J=$ $6.7 \mathrm{~Hz}, 1 \mathrm{H}), 3.87(\mathrm{~s}, 1 \mathrm{H}), 3.82-3.71(\mathrm{~m}, 2 \mathrm{H}), 3.13-2.99(\mathrm{~m}, 5 \mathrm{H})$, $2.82(\mathrm{~d}, J=13.0,7.0 \mathrm{~Hz}, 1 \mathrm{H}), 1.95(\mathrm{~d}, J=3.5 \mathrm{~Hz}, 1 \mathrm{H}), 1.64-1.57$ $(\mathrm{m}, 1 \mathrm{H}), 1.51(\mathrm{~d}, J=6.5 \mathrm{~Hz}, 3 \mathrm{H}), 1.51-1.44(\mathrm{~m}, 1 \mathrm{H}$, overlapping $)$, $1.35(\mathrm{~s}, 9 \mathrm{H}), 1.11-1.02(\mathrm{~m}, 1 \mathrm{H}), 0.86-0.83(\mathrm{~m}, 6 \mathrm{H}) \mathrm{ppm} .{ }^{13} \mathrm{C}$ NMR $\left(125 \mathrm{MHz}, \mathrm{CDCl}_{3}\right) \delta 156.18,151.09,137.85,137.28,129.72$, $128.65,127.80,126.61,126.22,79.88,72.82,69.82,57.41,54.73$, 53.82, 35.60, 33.51, 28.41, 26.56, 25.60, 17.02, 11.17 ppm. HRMS (ESI) $m / z:[\mathrm{M}+\mathrm{H}]^{+}$calcd for $\mathrm{C}_{28} \mathrm{H}_{43} \mathrm{~N}_{2} \mathrm{O}_{6} \mathrm{~S}$, 535.2836; found 535.2835 .

tert-Butyl ((2S,3R)-4-((N-(2-Ethylbutyl)-4-((R)-1-hydroxyethyl)phenyl)sulfonamido)-3-hydroxy-1-phenylbutan-2-yl)carbamate (10c). The same procedure was used as described above for compound 9a. Compound $8 \mathrm{c}(1.00 \mathrm{~g}, 1.83 \mathrm{mmol})$ was treated with (S)-2-methyl-CBS-oxazaborolidine (1.01 g, $3.66 \mathrm{mmol})$ and borane solution (1 M in THF) $(2.74 \mathrm{~mL}, 2.74 \mathrm{mmol})$ to give compound $10 \mathrm{c}$ as a white solid (yield after recrystallization: $0.71 \mathrm{~g}, 69 \%$ ). ${ }^{1} \mathrm{H}$ NMR $\left(500 \mathrm{MHz}, \mathrm{CDCl}_{3}\right) \delta 7.75(\mathrm{~d}, J=8.5 \mathrm{~Hz}, 2 \mathrm{H}), 7.52(\mathrm{~d}, J=8.3 \mathrm{~Hz}, 2$ $\mathrm{H}), 7.31-7.28(\mathrm{~m}, 2 \mathrm{H}), 7.25-7.20(\mathrm{~m}, 3 \mathrm{H}), 5.00-4.96(\mathrm{~m}, 1 \mathrm{H})$, $4.58(\mathrm{~d}, J=5.5 \mathrm{~Hz}, 1 \mathrm{H}), 3.93(\mathrm{~s}, 1 \mathrm{H}), 3.79-3.71(\mathrm{~m}, 2 \mathrm{H}), 3.12-$ $2.99(\mathrm{~m}, 4 \mathrm{H}), 2.92-2.85(\mathrm{~m}, 2 \mathrm{H}), 1.96(\mathrm{~d}, J=3.4 \mathrm{~Hz}, 1 \mathrm{H}), 1.51(\mathrm{~d}$, $J=6.5 \mathrm{~Hz}, 3 \mathrm{H}), 1.48-1.37(\mathrm{~m}, 2 \mathrm{H}), 1.34(\mathrm{~s}, 9 \mathrm{H}), 1.34-1.18(\mathrm{~m}, 3$ $\mathrm{H}$, overlapping), $0.83-0.79(\mathrm{~m}, 6 \mathrm{H}) \mathrm{ppm} .{ }^{13} \mathrm{C}$ NMR $(125 \mathrm{MHz}$, $\left.\mathrm{CDCl}_{3}\right) \delta 156.15,151.09,137.83,137.15,129.72,128.64,127.82$, $126.60,126.24,79.86,73.07,69.83,54.93,54.68,53.83,39.10,35.78$ 28.40, 25.60, 23.18, 22.86, 10.70, $10.42 \mathrm{ppm}$. HRMS (ESI) $\mathrm{m} / z$ : [M $+\mathrm{H}]^{+}$calcd for $\mathrm{C}_{29} \mathrm{H}_{45} \mathrm{~N}_{2} \mathrm{O}_{6} \mathrm{~S}$, 549.2993; found 549.2992.

$(3 R, 3 a S, 6 a R)-H e x a h y d r o f u r o[2,3-b]$ furan-3-yl ((2S,3R)-3-Hydroxy-4-((4-((S)-1-hydroxyethyl)-N-isobutylphenyl)sulfonamido)-1- phenylbutan-2-yl)carbamate (12). A solution of compound 9a (0.45 $\mathrm{g}, 0.864 \mathrm{mmol})$ in anhydrous dichloromethane $(6 \mathrm{~mL})$ was treated with trifluoroacetic acid $(5 \mathrm{~mL})$. After the reaction mixture was stirred at room temperature for $1 \mathrm{~h}$, solvents were evaporated under reduced pressure and the residue was dried under high vacuum. A solution of the resulting amine salt in anhydrous acetonitrile $(15 \mathrm{~mL})$ was cooled to $0{ }^{\circ} \mathrm{C}$ and treated with diisopropylethylamine $(0.34 \mathrm{~g}, 2.59 \mathrm{mmol})$ followed by bis-THF activated carbonate $11(0.23 \mathrm{~g}, 0.864 \mathrm{mmol})$. After $15 \mathrm{~min}$, the reaction mixture was allowed to warm to room temperature and stirred for $24 \mathrm{~h}$. The solvents were removed under reduced pressure, and the residue was purified by automated flash chromatography using a silica gel column (RediSep Gold, 24 g, gradient elution with $0-10 \%$ methanol/dichloromethane) to give the target compound $12(0.44 \mathrm{~g}, 88 \%)$ as a white solid. ${ }^{1} \mathrm{H}$ NMR (500 $\left.\mathrm{MHz}, \mathrm{CDCl}_{3}\right) \delta 7.75(\mathrm{~d}, J=8.2 \mathrm{~Hz}, 2 \mathrm{H}), 7.54(\mathrm{~d}, J=8.2 \mathrm{~Hz}, 2 \mathrm{H})$, $7.30-7.27(\mathrm{~m}, 2 \mathrm{H}), 7.22-7.19(\mathrm{~m}, 3 \mathrm{H}), 5.64(\mathrm{~d}, J=5.2 \mathrm{~Hz}, 1 \mathrm{H})$, $5.02-4.96(\mathrm{~m}, 2 \mathrm{H}), 4.90(\mathrm{~d}, J=8.4 \mathrm{~Hz}, 1 \mathrm{H}), 3.96-3.83(\mathrm{~m}, 4 \mathrm{H})$, $3.70-3.65(\mathrm{~m}, 2 \mathrm{H}), 3.60$ (br s, $1 \mathrm{H}), 3.19-3.14(\mathrm{~m}, 1 \mathrm{H}), 3.08$ (dd, $J$ $=14.0,3.6 \mathrm{~Hz}, 1 \mathrm{H}), 3.03-2.97(\mathrm{~m}, 2 \mathrm{H}), 2.92-2.77(\mathrm{~m}, 3 \mathrm{H}), 2.06$ (br s, $1 \mathrm{H}), 1.87-1.81(\mathrm{~m}, 1 \mathrm{H}), 1.68-1.57(\mathrm{~m}, 1 \mathrm{H}), 1.52(\mathrm{~d}, J=6.5$ $\mathrm{Hz}, 3 \mathrm{H}$, overlapping), $1.51-1.47(\mathrm{~m}, 1 \mathrm{H}), 0.94(\mathrm{~d}, J=6.6 \mathrm{~Hz}, 3 \mathrm{H})$, $0.89(\mathrm{~d}, J=6.6 \mathrm{~Hz}, 3 \mathrm{H}) \mathrm{ppm} .{ }^{13} \mathrm{C} \mathrm{NMR}\left(100 \mathrm{MHz}, \mathrm{CDCl}_{3}\right) \delta$ $155.60,151.33$, 137.63, 136.92, 129.48, 128.72, 127.74, 126.77, $126.34,109.44,73.59,72.95,70.98,69.74,59.09,55.21,53.96,45.44$, $35.79,27.46,25.99,25.59,20.29,20.00 \mathrm{ppm}$. HRMS (ESI) $\mathrm{m} / z:[\mathrm{M}$ $+\mathrm{H}]^{+}$calcd for $\mathrm{C}_{29} \mathrm{H}_{41} \mathrm{~N}_{2} \mathrm{O}_{8} \mathrm{~S}$, 577.2578; found 577.2575. Anal. HPLC: $t_{\mathrm{R}} 11.22$ min, purity $97 \%$.

(3R,3aS,6aR)-Hexahydrofuro[2,3-b]furan-3-yl ((2S,3R)-3-Hydroxy-4-((4-((R)-1-hydroxyethyl)- $N$-isobutylphenyl)sulfonamido)-1phenylbutan-2-yl)carbamate (13). The same procedure was used as described above for compound 12. Compound 10a (0.40 g, 0.768 $\mathrm{mmol}$ ) was treated with trifluoroacetic acid $(5 \mathrm{~mL})$, and the resulting deprotected amine was treated with diisopropylethylamine $(0.30 \mathrm{~g}$, $2.304 \mathrm{mmol}$ ) and bis-THF activated carbonate 11 (0.21 g, 0.768 $\mathrm{mmol})$ to give compound $13(0.40 \mathrm{~g}, 90 \%)$ as a white solid. ${ }^{1} \mathrm{H}$ NMR $\left(500 \mathrm{MHz}, \mathrm{CDCl}_{3}\right) \delta 7.74(\mathrm{~d}, J=8.3 \mathrm{~Hz}, 2 \mathrm{H}), 7.53(\mathrm{~d}, J=8.3 \mathrm{~Hz}, 2$ H), 7.29-7.26 (m, $2 \mathrm{H}), 7.22-7.19(\mathrm{~m}, 3 \mathrm{H}), 5.63(\mathrm{~d}, J=5.2 \mathrm{~Hz}, 1$ $\mathrm{H})$, 5.01-4.95 (m, $3 \mathrm{H})$, 3.94-3.81 (m, $4 \mathrm{H}), 3.69-3.60(\mathrm{~m}, 3 \mathrm{H})$, $3.17-3.12(\mathrm{~m}, 1 \mathrm{H}), 3.08(\mathrm{dd}, J=14.0,3.6 \mathrm{~Hz}, 1 \mathrm{H}), 3.05-2.96(\mathrm{~m}$, $2 \mathrm{H}), 2.90-2.76(\mathrm{~m}, 3 \mathrm{H}), 2.27(\mathrm{br} \mathrm{s}, 1 \mathrm{H}), 1.89-1.81(\mathrm{~m}, 1 \mathrm{H})$, $1.66-1.58(\mathrm{~m}, 1 \mathrm{H}), 1.50(\mathrm{~d}, J=6.5 \mathrm{~Hz}, 3 \mathrm{H}$, overlapping), $1.50-$ $1.44(\mathrm{~m}, 1 \mathrm{H}), 0.93(\mathrm{~d}, J=6.6 \mathrm{~Hz}, 3 \mathrm{H}), 0.89(\mathrm{~d}, J=6.6 \mathrm{~Hz}, 3 \mathrm{H})$ ppm. ${ }^{13} \mathrm{C}$ NMR $\left(100 \mathrm{MHz}, \mathrm{CDCl}_{3}\right) \delta 155.59,151.34,137.62,136.89$, $129.48,128.73$, 127.76, 126.78, 126.32, 109.44, 73.61, 72.95, 71.01, 69.75, 59.14, 55.21, 54.01, 45.43, 35.83, 27.47, 26.00, 25.62, 20.29, $20.00 \mathrm{ppm}$. HRMS (ESI) $\mathrm{m} / z$ : $[\mathrm{M}+\mathrm{H}]^{+}$calcd for $\mathrm{C}_{29} \mathrm{H}_{41} \mathrm{~N}_{2} \mathrm{O}_{8} \mathrm{~S}$, 577.2578; found 577.2581. Anal. HPLC: $t_{\mathrm{R}} 11.37 \mathrm{~min}$, purity $99 \%$.

(3R,3aS,6aR)-Hexahydrofuro[2,3-b]furan-3-yl ((2S,3R)-3-Hydroxy-4-((4-((S)-1-hydroxyethyl)-N-((S)-2-methylbutyl) phenyl)sulfonamido)-1-phenylbutan-2-yl)carbamate (14). The same procedure was used as described above for compound 12. Compound $\mathbf{9 b}$ $(0.43 \mathrm{~g}, 0.804 \mathrm{mmol})$ was treated with trifluoroacetic acid $(5 \mathrm{~mL})$, and the resulting deprotected amine was treated with diisopropylethylamine $(0.31 \mathrm{~g}, 2.41 \mathrm{mmol})$ and bis-THF activated carbonate 11 $(0.22 \mathrm{~g}, 0.804 \mathrm{mmol})$ to give compound $14(0.41 \mathrm{~g}, 86 \%)$ as a white solid. ${ }^{1} \mathrm{H}$ NMR $\left(500 \mathrm{MHz}, \mathrm{CDCl}_{3}\right) \delta 7.75(\mathrm{~d}, J=8.3 \mathrm{~Hz}, 2 \mathrm{H}), 7.53$ $(\mathrm{d}, J=8.2 \mathrm{~Hz}, 2 \mathrm{H}), 7.30-7.27(\mathrm{~m}, 2 \mathrm{H}), 7.22-7.20(\mathrm{~m}, 3 \mathrm{H}), 5.64$ $(\mathrm{d}, J=5.2 \mathrm{~Hz}, 1 \mathrm{H}), 5.03-4.96(\mathrm{~m}, 2 \mathrm{H}), 4.89(\mathrm{~d}, J=8.9 \mathrm{~Hz}, 1 \mathrm{H})$, $3.94(\mathrm{dd}, J=9.5,6.0 \mathrm{~Hz}, 1 \mathrm{H}), 3.91-3.83(\mathrm{~m}, 3 \mathrm{H}), 3.71-3.65(\mathrm{~m}, 2$ $\mathrm{H}), 3.56$ (br s, $1 \mathrm{H}), 3.17-2.98(\mathrm{~m}, 4 \mathrm{H}), 2.92-2.87$ (m, $1 \mathrm{H}), 2.84-$ $2.80(\mathrm{~m}, 2 \mathrm{H}), 2.10$ (br s, $1 \mathrm{H}), 1.69-1.59(\mathrm{~m}, 2 \mathrm{H}), 1.54-1.46(\mathrm{~m}, 2$ $\mathrm{H}), 1.51(\mathrm{~d}, J=6.5 \mathrm{~Hz}, 3 \mathrm{H}$, overlapping $), 1.14-1.05(\mathrm{~m}, 1 \mathrm{H}), 0.88-$ $0.85(\mathrm{~m}, 6 \mathrm{H}) \mathrm{ppm} .{ }^{13} \mathrm{C} \mathrm{NMR}\left(125 \mathrm{MHz}, \mathrm{CDCl}_{3}\right) \delta 155.61,151.35$, 137.60, 136.93, 129.52, 128.74, 127.77, 126.79, 126.33, 109.44, 73.62, $72.83,70.98,69.73,57.60,55.20,53.90,45.46,35.81,33.63,26.54$, $25.98,25.57,17.05,11.18 \mathrm{ppm}$. HRMS (ESI) $\mathrm{m} / z:[\mathrm{M}+\mathrm{H}]^{+}$calcd for $\mathrm{C}_{30} \mathrm{H}_{43} \mathrm{~N}_{2} \mathrm{O}_{8} \mathrm{~S}$, 591.2735; found 591.2732. Anal. HPLC: $t_{\mathrm{R}} 11.95$ min, purity $99 \%$.

(3R,3aS,6aR)-Hexahydrofuro[2,3-b]furan-3-yl ((2S,3R)-3-Hydroxy-4-((4-((R)-1-hydroxyethyl)-N-((S)-2-methylbutyl)phenyl)- 
sulfonamido)-1-phenylbutan-2-yl)carbamate (15). The same procedure was used as described above for compound 12. Compound $10 \mathrm{~b}(0.40 \mathrm{~g}, 0.748 \mathrm{mmol})$ was treated with trifluoroacetic acid (5 $\mathrm{mL}$ ), and the resulting deprotected amine was treated with diisopropylethylamine $(0.29 \mathrm{mg}, 2.24 \mathrm{mmol})$ and bis-THF activated carbonate $11(0.20 \mathrm{~g}, 0.748 \mathrm{mmol})$ to give compound $15(0.40 \mathrm{~g}$, 91\%) as a white solid. ${ }^{1} \mathrm{H} \mathrm{NMR}\left(500 \mathrm{MHz}, \mathrm{CDCl}_{3}\right) \delta 7.75(\mathrm{~d}, J=8.4$ $\mathrm{Hz}, 2 \mathrm{H}), 7.54(\mathrm{~d}, J=8.3 \mathrm{~Hz}, 2 \mathrm{H}), 7.30-7.27(\mathrm{~m}, 2 \mathrm{H}), 7.23-7.20$ $(\mathrm{m}, 3 \mathrm{H}), 5.65(\mathrm{~d}, J=5.2 \mathrm{~Hz}, 1 \mathrm{H}), 5.03-4.96(\mathrm{~m}, 2 \mathrm{H}), 4.86(\mathrm{~d}, J=$ $9.0 \mathrm{~Hz}, 1 \mathrm{H}), 3.94(\mathrm{dd}, J=9.5,6.0 \mathrm{~Hz}, 1 \mathrm{H}), 3.91-3.84(\mathrm{~m}, 3 \mathrm{H})$, $3.72-3.64(\mathrm{~m}, 2 \mathrm{H}), 3.55(\mathrm{br} \mathrm{s}, 1 \mathrm{H}), 3.14(\mathrm{dd}, J=15.0,8.5 \mathrm{~Hz}, 1 \mathrm{H})$, $3.10-3.04(\mathrm{~m}, 2 \mathrm{H}), 2.99$ (dd, $J=15.0,3.0 \mathrm{~Hz}, 1 \mathrm{H}), 2.92-2.87(\mathrm{~m}$, $1 \mathrm{H}), 2.85-2.80(\mathrm{~m}, 2 \mathrm{H}), 2.05($ br s, $1 \mathrm{H}), 1.70-1.55(\mathrm{~m}, 2 \mathrm{H})$, 1.54-1.47 (m, $2 \mathrm{H}), 1.52$ (d, $J=6.5 \mathrm{~Hz}, 3 \mathrm{H}$, overlapping), 1.14$1.05(\mathrm{~m}, 1 \mathrm{H}), 0.88-0.85(\mathrm{~m}, 6 \mathrm{H}) \mathrm{ppm} .{ }^{13} \mathrm{C}$ NMR $(125 \mathrm{MHz}$, $\left.\mathrm{CDCl}_{3}\right) \delta 155.61,151.38,137.59,136.90,129.52,128.74,127.78$, $126.80,126.31,109.45,73.62,72.83,71.01,69.73,57.64,55.19,53.93$, 45.46, 35.85, 33.64, 26.56, 25.99, 25.59, 17.05, 11.18 ppm. HRMS (ESI) $\mathrm{m} / z$ : $[\mathrm{M}+\mathrm{H}]^{+}$calcd for $\mathrm{C}_{30} \mathrm{H}_{43} \mathrm{~N}_{2} \mathrm{O}_{8} \mathrm{~S}$, 591.2735; found 591.2734. Anal. HPLC: $t_{\mathrm{R}} 11.87 \mathrm{~min}$, purity $99 \%$.

$(3 R, 3 a S, 6 a R)-H e x a h y d r o f u r o[2,3-b] f u r a n-3-y l \quad((2 S, 3 R)-4-((N-(2-$ Ethylbutyl)-4-((S)-1-hydroxyethyl)phenyl)sulfonamido)-3-hydroxy1-phenylbutan-2-yl)carbamate (16). The same procedure was used as described above for compound 12. Compound 9c (0.40 g, 0.729 $\mathrm{mmol})$ was treated with trifluoroacetic acid $(5 \mathrm{~mL})$, and the resulting deprotected amine was treated with diisopropylethylamine $(0.28 \mathrm{~g}$, $2.19 \mathrm{mmol})$ and bis-THF activated carbonate 11 (0.22 g, 0.801 $\mathrm{mmol})$ to give compound $16(0.36 \mathrm{~g}, 82 \%)$ as a white solid. ${ }^{1} \mathrm{H}$ NMR $\left(500 \mathrm{MHz}, \mathrm{CDCl}_{3}\right) \delta 7.75(\mathrm{~d}, J=8.4 \mathrm{~Hz}, 2 \mathrm{H}), 7.54(\mathrm{~d}, J=8.3 \mathrm{~Hz}, 2$ H), 7.30-7.27 (m, $2 \mathrm{H}), 7.22-7.20(\mathrm{~m}, 3 \mathrm{H}), 5.64(\mathrm{~d}, J=5.2 \mathrm{~Hz}, 1$ $\mathrm{H}), 5.02-4.97(\mathrm{~m}, 2 \mathrm{H}), 4.84(\mathrm{~d}, J=9.1 \mathrm{~Hz}, 1 \mathrm{H}), 3.94(\mathrm{~d}, J=9.5$, $6.0 \mathrm{~Hz}, 1 \mathrm{H}), 3.88-3.80(\mathrm{~m}, 3 \mathrm{H}), 3.70-3.64(\mathrm{~m}, 3 \mathrm{H}), 3.17-3.06$ $(\mathrm{m}, 3 \mathrm{H}), 2.98(\mathrm{dd}, J=15.0,3.0 \mathrm{~Hz}, 1 \mathrm{H}), 2.92-2.85(\mathrm{~m}, 2 \mathrm{H}), 2.81$ $(\mathrm{dd}, J=14.0,9.0 \mathrm{~Hz}, 1 \mathrm{H}), 2.02($ br s, $1 \mathrm{H}), 1.68-1.60(\mathrm{~m}, 1 \mathrm{H})$, $1.55-1.42(\mathrm{~m}, 3 \mathrm{H}), 1.52(\mathrm{~d}, J=6.5 \mathrm{~Hz}, 3 \mathrm{H}$, overlapping), $1.35-1.25$ $(\mathrm{m}, 3 \mathrm{H}), 0.85-0.81(\mathrm{~m}, 6 \mathrm{H}) \mathrm{ppm} .{ }^{13} \mathrm{C}$ NMR $\left(100 \mathrm{MHz}, \mathrm{CDCl}_{3}\right) \delta$ $155.58,151.34,137.57,136.69,129.50,128.74,127.79,126.78$ $126.35,109.43,73.60,73.19,70.91,69.75,55.11,53.95,45.44,39.26$, $35.93,25.97,25.59,23.16,22.85,10.77,10.41 \mathrm{ppm}$. HRMS (ESI) m/ $z:[\mathrm{M}+\mathrm{H}]^{+}$calcd for $\mathrm{C}_{31} \mathrm{H}_{45} \mathrm{~N}_{2} \mathrm{O}_{8} \mathrm{~S}, 605.2891$; found 605.2890. Anal. HPLC: $t_{\mathrm{R}} 12.56 \mathrm{~min}$, purity $99 \%$.

$(3 R, 3 a S, 6 a R)-$ Hexahydrofuro[2,3-b]furan-3-yl $\quad((2 S, 3 R)-4-((N-(2-$ Ethylbutyl)-4-((R)-1-hydroxyethyl)phenyl)sulfonamido)-3-hydroxy1-phenylbutan-2-yl)carbamate (17). The same procedure was used as described above for compound 12. Compound 10c (0.40 g, 0.729 $\mathrm{mmol})$ was treated with trifluoroacetic acid $(5 \mathrm{~mL})$, and the resulting deprotected amine was treated with diisopropylethylamine $(0.28 \mathrm{~g}$, $2.19 \mathrm{mmol})$ and bis-THF activated carbonate 11 (0.28 g, 0.801 mmol $)$ to give compound $\mathbf{1 7}(0.32 \mathrm{~g}, 73 \%)$ as a white solid. ${ }^{1} \mathrm{H}$ NMR $\left(500 \mathrm{MHz}, \mathrm{CDCl}_{3}\right) \delta 7.75(\mathrm{~d}, J=8.3 \mathrm{~Hz}, 2 \mathrm{H}), 7.54(\mathrm{~d}, J=8.2 \mathrm{~Hz}, 2$ H), 7.30-7.27 (m, $2 \mathrm{H}), 7.23-7.20(\mathrm{~m}, 3 \mathrm{H}), 5.64(\mathrm{~d}, J=5.2 \mathrm{~Hz}, 1$ H), $5.02-4.97(\mathrm{~m}, 2 \mathrm{H}), 4.84(\mathrm{~d}, J=8.5 \mathrm{~Hz}, 1 \mathrm{H}), 4.93(\mathrm{dd}, J=10.0$, $6.5 \mathrm{~Hz}, 1 \mathrm{H}), 3.87-3.80(\mathrm{~m}, 3 \mathrm{H}), 3.71-3.64(\mathrm{~m}, 3 \mathrm{H}), 3.16-3.06$ $(\mathrm{m}, 3 \mathrm{H}), 2.99-2.96(\mathrm{dd}, J=15.5,2.5 \mathrm{~Hz}, 1 \mathrm{H}), 2.92-2.86(\mathrm{~m}, 2 \mathrm{H})$, $2.80(\mathrm{dd}, J=14.0,9.2 \mathrm{~Hz}, 1 \mathrm{H}), 2.06(\mathrm{br} \mathrm{s}, 1 \mathrm{H}), 1.66-1.60(\mathrm{~m}, 1 \mathrm{H})$, $1.53-1.40(\mathrm{~m}, 3 \mathrm{H}), 1.52(\mathrm{~d}, J=6.5 \mathrm{~Hz}, 3 \mathrm{H}$, overlapping), $1.35-1.25$ $(\mathrm{m}, 3 \mathrm{H}), 0.85-0.81(\mathrm{~m}, 6 \mathrm{H}) \mathrm{ppm} .{ }^{13} \mathrm{C} \mathrm{NMR}\left(100 \mathrm{MHz}, \mathrm{CDCl}_{3}\right) \delta$ $155.57,151.46,137.65,136.56,129.45,128.65,127.71,126.68$, $126.29,109.40,73.51,73.18,70.95,69.72,69.59,55.16,54.97,53.81$, $45.45,39.12,35.90,25.94,25.52,23.07,22.81,10.67,10.40 \mathrm{ppm}$. HRMS (ESI) $m / z:[\mathrm{M}+\mathrm{H}]^{+}$calcd for $\mathrm{C}_{31} \mathrm{H}_{45} \mathrm{~N}_{2} \mathrm{O}_{8} \mathrm{~S}$, 605.2891; found 605.2891. Anal. HPLC: $t_{\mathrm{R}} 12.61 \mathrm{~min}$, purity $100 \%$.

tert-Butyl ((2S,3R)-4-((4-((R)-1,2-Dihydroxyethyl)-Nisobutylphenyl)sulfonamido)-3-hydroxy-1-phenylbutan-2-yl)carbamate (20a). t-Butanol $(7.5 \mathrm{~mL})$ and water $(7.5 \mathrm{~mL})$ were charged into a round-bottom flask, and $\mathrm{AD}-\mathrm{mix}-\beta(2.80 \mathrm{~g})$ was added. The mixture was stirred at room temperature until two clear phases appeared. The mixture was cooled to $0{ }^{\circ} \mathrm{C}$, and intermediate 19a $(0.86 \mathrm{~g}, 1.71 \mathrm{mmol})$ was added in one portion. The resulting reaction mixture was stirred at $4{ }^{\circ} \mathrm{C}$ for $48 \mathrm{~h}$. Reaction was quenched by adding sodium sulfite $(3.00 \mathrm{~g})$, and the mixture was allowed to warm to room temperature. Ethyl acetate $(10 \mathrm{~mL})$ was added, phases were separated, and the aqueous layer was extracted with ethyl acetate $(3 \times$ $10 \mathrm{~mL})$. The combined organic portions were dried $\left(\mathrm{Na}_{2} \mathrm{SO}_{4}\right)$, filtered, and concentrated. The residue was purified by automated flash chromatography using a silica gel column (RediSep Gold, $40 \mathrm{~g}$, gradient elution with $20-100 \%$ ethyl acetate/hexanes) to give compound 20a as a white solid $(0.80 \mathrm{~g}, 87 \%) .{ }^{1} \mathrm{H}$ NMR (500 $\left.\mathrm{MHz}, \mathrm{CDCl}_{3}\right) \delta 7.75(\mathrm{~d}, J=8.4 \mathrm{~Hz}, 2 \mathrm{H}), 7.52(\mathrm{~d}, J=8.3 \mathrm{~Hz}, 2 \mathrm{H})$, $7.31-7.28(\mathrm{~m}, 2 \mathrm{H}), 7.24-7.20(\mathrm{~m}, 3 \mathrm{H}), 4.88(\mathrm{~d}, J=6.0 \mathrm{~Hz}, 1 \mathrm{H})$, $4.65(\mathrm{~d}, J=7.4 \mathrm{~Hz}, 1 \mathrm{H}), 3.93(\mathrm{~s}, 1 \mathrm{H}), 3.83-3.70(\mathrm{~m}, 3 \mathrm{H}), 3.62$ (dd, $J=11.0,8.0 \mathrm{~Hz}, 1 \mathrm{H}), 3.14-3.07(\mathrm{~m}, 2 \mathrm{H}), 3.01-2.82(\mathrm{~m}, 5 \mathrm{H})$, $2.31(\mathrm{~s}, 1 \mathrm{H}), 1.89-1.81(\mathrm{~m}, 1 \mathrm{H}), 1.34(\mathrm{~s}, 9 \mathrm{H}), 0.90(\mathrm{~d}, J=6.5 \mathrm{~Hz}$, $3 \mathrm{H}), 0.86(\mathrm{~d}, J=6.5 \mathrm{~Hz}, 3 \mathrm{H}) \mathrm{ppm} .{ }^{13} \mathrm{C}$ NMR $\left(125 \mathrm{MHz} \mathrm{CDCl}_{3}\right) \delta$ $156.27,145.97,137.93,137.89,129.67,128.64,127.68,126.97$, $126.62,79.99,74.00,72.88,67.88,58.70,54.89,53.73,35.58,28.39$, 27.30, 20.24, $20.00 \mathrm{ppm}$. HRMS (ESI) $\mathrm{m} / z$ : $[\mathrm{M}+\mathrm{H}]^{+}$calcd for $\mathrm{C}_{27} \mathrm{H}_{41} \mathrm{~N}_{2} \mathrm{O}_{7} \mathrm{~S}$, 537.2629; found 537.2627.

tert-Butyl ((2S,3R)-4-((4- ((R)-1,2-Dihydroxyethyl)- N-((S)-2methylbutyl)phenyl)sulfonamido)-3-hydroxy-1-phenylbutan-2-yl)carbamate (20b). The same procedure was used as described above for compound 20a. Compound $19 \mathrm{~b}(1.22 \mathrm{~g}, 2.36 \mathrm{mmol})$ was treated with $\mathrm{AD}$-mix $-\beta(2.80 \mathrm{~g})$ and the reaction was quenched with solid sodium sulfite $(3.00 \mathrm{~g})$ to give compound $20 \mathrm{~b}$ as a white solid $(0.88 \mathrm{~g}$, 68\%). ${ }^{1} \mathrm{H}$ NMR $\left(500 \mathrm{MHz}, \mathrm{CDCl}_{3}\right) \delta 7.70(\mathrm{~d}, J=8.5 \mathrm{~Hz}, 2 \mathrm{H}), 7.48$ $(\mathrm{d}, J=8.0 \mathrm{~Hz}, 2 \mathrm{H}), 7.29-7.25(\mathrm{~m}, 2 \mathrm{H}), 7.22-7.18(\mathrm{~m}, 3 \mathrm{H}), 4.84-$ $4.82(\mathrm{~m}, 1 \mathrm{H}), 4.74(\mathrm{~d}, J=7.4 \mathrm{~Hz}, 1 \mathrm{H}), 3.97(\mathrm{~s}, 1 \mathrm{H}), 3.80-3.69(\mathrm{~m}$, $4 \mathrm{H}), 3.58-3.55(\mathrm{~m}, 1 \mathrm{H}), 3.14-3.04(\mathrm{~m}, 3 \mathrm{H}), 3.02-2.93(\mathrm{~m}, 2 \mathrm{H})$, $2.90-2.79(\mathrm{~m}, 2 \mathrm{H}), 1.64-1.57(\mathrm{~m}, 1 \mathrm{H}), 1.47-1.39(\mathrm{~m}, 1 \mathrm{H}), 1.32$ (s, $9 \mathrm{H}), 1.08-0.99(\mathrm{~m}, 1 \mathrm{H}), 0.84-0.81(\mathrm{~m}, 6 \mathrm{H}) \mathrm{ppm} .{ }^{13} \mathrm{C}$ NMR $\left(125 \mathrm{MHz}, \mathrm{CDCl}_{3}\right) \delta 156.23,146.24,137.77,137.59,129.60,128.58$, $127.55,126.96,126.57,79.97,73.94,72.64,67.80,57.09,54.78,53.46$, $35.60,33.37,28.33,26.55,16.95,11.14 \mathrm{ppm}$. HRMS (ESI) $\mathrm{m} / z$ : [M $+\mathrm{H}]^{+}$calcd for $\mathrm{C}_{28} \mathrm{H}_{43} \mathrm{~N}_{2} \mathrm{O}_{7} \mathrm{~S}$, 551.2785; found 551.2786.

tert-Butyl ((2S,3R)-4-((4- $((R)-1,2-$ Dihydroxyethyl)-N-(2ethylbutyl)phenyl)sulfonamido)-3-hydroxy-1-phenylbutan-2-yl)carbamate (20c). The same procedure was used as described above for compound 20a. Compound 19c $(1.30 \mathrm{~g}, 2.45 \mathrm{mmol})$ was treated with $\mathrm{AD}$-mix- $\beta(3.50 \mathrm{~g})$, and the reaction was quenched with sodium sulfite $(4.00 \mathrm{~g})$ to give compound $20 \mathrm{c}$ as a white solid $(1.02 \mathrm{~g}, 74 \%)$. ${ }^{1} \mathrm{H}$ NMR $\left(500 \mathrm{MHz}, \mathrm{CDCl}_{3}\right) \delta 7.76(\mathrm{~d}, J=8.0 \mathrm{~Hz}, 2 \mathrm{H}), 7.53(\mathrm{~d}, J=$ $8.0 \mathrm{~Hz}, 2 \mathrm{H}), 7.31-7.28(\mathrm{~m}, 2 \mathrm{H}), 7.25-7.20(\mathrm{~m}, 3 \mathrm{H}), 4.90(\mathrm{~d}, J=$ $7.5 \mathrm{~Hz}, 1 \mathrm{H}), 4.58(\mathrm{~d}, J=7.0 \mathrm{~Hz}, 1 \mathrm{H}), 3.92(\mathrm{~s}, 1 \mathrm{H}), 3.82(\mathrm{~d}, J=11.0$ $\mathrm{Hz}, 1 \mathrm{H}), 3.77-3.71(\mathrm{~m}, 2 \mathrm{H}), 3.64(\mathrm{t}, J=10.0 \mathrm{~Hz}, 1 \mathrm{H}), 3.13-2.98$ $(\mathrm{m}, 4 \mathrm{H}), 2.92-2.81(\mathrm{~m}, 3 \mathrm{H}), 2.15(\mathrm{br} \mathrm{s}, 1 \mathrm{H}), 1.48-1.38(\mathrm{~m}, 2 \mathrm{H})$, $1.36-1.23(\mathrm{~m}, 3 \mathrm{H}), 1.34(\mathrm{~s}, 9 \mathrm{H}$, overlapping), 0.83-0.79 (m, $6 \mathrm{H})$ ppm. ${ }^{13} \mathrm{C}$ NMR $\left(125 \mathrm{MHz}, \mathrm{CDCl}_{3}\right) \delta 156.23,146.25,137.75,137.52$, $129.61,128.59,127.59,126.98,126.58,79.98,73.95,72.88,67.80$, 54.74, 54.61, 53.47, 38.95, 35.77, 28.34, 23.06, 22.81, 10.61, 10.41 ppm. HRMS (ESI) $m / z:[\mathrm{M}+\mathrm{H}]^{+}$calcd for $\mathrm{C}_{29} \mathrm{H}_{45} \mathrm{~N}_{2} \mathrm{O}_{7} \mathrm{~S}, 565.2942$; found 565.2939.

tert-Butyl ((2S,3R)-4-((4-((S)-1,2-Dihydroxyethyl)-Nisobutylphenyl)sulfonamido)-3-hydroxy-1-phenylbutan-2-yl)carbamate (21a). The same procedure was used as described above for compound 20a. Compound 19a $(0.65 \mathrm{~g}, 1.30 \mathrm{mmol})$ was treated with $\mathrm{AD}$-mix- $\alpha(2.10 \mathrm{~g})$, and the reaction was quenched with sodium sulfite $(2.5 \mathrm{~g})$ to give compound $21 \mathrm{a}$ as a white solid $(0.33 \mathrm{~g}, 47 \%)$ ${ }^{1} \mathrm{H}$ NMR $\left(500 \mathrm{MHz}, \mathrm{CDCl}_{3}\right) \delta 7.76(\mathrm{~d}, J=8.5 \mathrm{~Hz}, 2 \mathrm{H}), 7.52(\mathrm{~d}, J=$ $8.5 \mathrm{~Hz}, 2 \mathrm{H}), 7.31-7.28(\mathrm{~m}, 2 \mathrm{H}), 7.25-7.21(\mathrm{~m}, 3 \mathrm{H}), 4.91-4.88$ $(\mathrm{m}, 1 \mathrm{H}), 4.63(\mathrm{~d}, J=7.5 \mathrm{~Hz}, 1 \mathrm{H}), 3.92(\mathrm{~s}, 1 \mathrm{H}), 3.83-3.70(\mathrm{~m}, 3$ $\mathrm{H})$, 3.66-3.61 (m, $1 \mathrm{H}), 3.14-3.06(\mathrm{~m}, 2 \mathrm{H}), 3.02-2.81(\mathrm{~m}, 5 \mathrm{H})$, $2.13(\mathrm{t}, J=5.4 \mathrm{~Hz}, 1 \mathrm{H}), 1.89-1.81(\mathrm{~m}, 1 \mathrm{H}), 1.34(\mathrm{~s}, 9 \mathrm{H}), 0.90(\mathrm{~d}, J$ $=6.5 \mathrm{~Hz}, 3 \mathrm{H}), 0.86(\mathrm{~d}, J=6.5 \mathrm{~Hz}, 3 \mathrm{H}) \mathrm{ppm} .{ }^{13} \mathrm{C}$ NMR $(125 \mathrm{MHz}$, $\left.\mathrm{CDCl}_{3}\right) \delta 156.29,145.86,138.01,137.90,129.69,128.65,127.72$, $126.97,126.62,79.96,74.02,72.90,67.90,58.75,54.88,53.80,35.61$, $28.39,27.32,20.25,20.00 \mathrm{ppm}$. HRMS (ESI) $\mathrm{m} / z:[\mathrm{M}+\mathrm{H}]^{+}$calcd for $\mathrm{C}_{27} \mathrm{H}_{41} \mathrm{~N}_{2} \mathrm{O}_{7} \mathrm{~S}$, 537.2629; found 537.2631.

tert-Butyl ((2S,3R)-4-((4-((S)-1,2-Dihydroxyethyl)-N-((S)-2methylbutyl)phenyl)sulfonamido)-3-hydroxy-1-phenylbutan-2-yl)carbamate (21b). The same procedure was used as described above 
for compound 20a. Compound $19 \mathrm{~b}(1.00 \mathrm{~g}, 1.94 \mathrm{mmol})$ was treated with $\mathrm{AD}$-mix- $\alpha(2.80 \mathrm{~g})$, and the reaction was quenched with solid sodium sulfite $(3.00 \mathrm{~g})$ to give compound $21 \mathrm{~b}$ as a white solid $(0.92 \mathrm{~g}$, 86\%). ${ }^{1} \mathrm{H}$ NMR (500 MHz, $\left.\mathrm{CDCl}_{3}\right) \delta 7.75(\mathrm{~d}, J=8.5 \mathrm{~Hz}, 2 \mathrm{H}), 7.52$ (d, $J=8.5 \mathrm{~Hz}, 2 \mathrm{H}), 7.31-7.28(\mathrm{~m}, 2 \mathrm{H}), 7.25-7.20(\mathrm{~m}, 3 \mathrm{H}), 4.91-$ $4.88(\mathrm{~m}, 1 \mathrm{H}), 4.62(\mathrm{~d}, J=7.1 \mathrm{~Hz}, 1 \mathrm{H}), 3.87(\mathrm{br} \mathrm{s}, 1 \mathrm{H}), 3.83-3.71$ (m, $3 \mathrm{H}), 3.66-3.61(\mathrm{~m}, 1 \mathrm{H}), 3.13-2.87(\mathrm{~m}, 5 \mathrm{H}), 2.85-2.80(\mathrm{~m}, 2$ $\mathrm{H}), 2.16(\mathrm{t}, J=5.5 \mathrm{~Hz}, 1 \mathrm{H}), 1.65-1.58(\mathrm{~m}, 1 \mathrm{H}), 1.51-1.43(\mathrm{~m}, 1$ $\mathrm{H}), 1.35(\mathrm{~s}, 9 \mathrm{H}), 1.10-1.02(\mathrm{~m}, 1 \mathrm{H}), 0.86-0.83(\mathrm{~m}, 6 \mathrm{H}) \mathrm{ppm} .{ }^{13} \mathrm{C}$ NMR $\left(125 \mathrm{MHz}, \mathrm{CDCl}_{3}\right) \delta 156.22,145.86,137.92,137.80,129.70$, $128.66,127.73,126.96,126.64,79.96,74.02,72.77,67.90,57.32$, 54.78, 53.71, 35.63, 33.49, 28.40, 26.56, 17.01, 11.18 ppm. HRMS (ESI) $\mathrm{m} / z:[\mathrm{M}+\mathrm{H}]^{+}$calcd for $\mathrm{C}_{28} \mathrm{H}_{43} \mathrm{~N}_{2} \mathrm{O}_{7} \mathrm{~S}$, 551.2785; found 551.2787.

tert-Butyl ((2S,3R)-4-((4-((S)-1,2-Dihydroxyethyl)-N-(2ethylbutyl)phenyl)sulfonamido)-3-hydroxy-1-phenylbutan-2-yl)carbamate $(21 \mathrm{c})$. The same procedure was used as described above for compound 20a. Compound 19c $(1.50 \mathrm{~g}, 2.45 \mathrm{mmol})$ was treated with $\mathrm{AD}$-mix- $\alpha(3.80 \mathrm{~g})$, and the reaction was quenched with sodium sulfite $(4.00 \mathrm{~g})$ to give compound $21 \mathrm{c}$ as a white solid $(0.95 \mathrm{~g}, 60 \%)$. ${ }^{1} \mathrm{H}$ NMR $\left(500 \mathrm{MHz}, \mathrm{CDCl}_{3}\right) \delta 7.76(\mathrm{~d}, J=8.5 \mathrm{~Hz}, 2 \mathrm{H}), 7.53(\mathrm{~d}, J=$ $8.5 \mathrm{~Hz}, 2 \mathrm{H}), 7.31-7.28(\mathrm{~m}, 2 \mathrm{H}), 7.25-7.20(\mathrm{~m}, 3 \mathrm{H}), 4.92-4.89$ $(\mathrm{m}, 1 \mathrm{H}), 4.58(\mathrm{~d}, J=7.0 \mathrm{~Hz}, 1 \mathrm{H}), 3.93(\mathrm{~s}, 1 \mathrm{H}), 3.84-3.80(\mathrm{~m}, 1$ $\mathrm{H}), 3.77-3.71(\mathrm{~m}, 2 \mathrm{H}), 3.66-3.62(\mathrm{~m}, 1 \mathrm{H}), 3.13-2.98(\mathrm{~m}, 4 \mathrm{H})$, $2.93-2.77(\mathrm{~m}, 3 \mathrm{H}), 2.16-2.08(\mathrm{~m}, 1 \mathrm{H}), 1.48-1.37(\mathrm{~m}, 2 \mathrm{H}), 1.36-$ $1.20(\mathrm{~m}, 3 \mathrm{H}), 1.34(\mathrm{~s}, 9 \mathrm{H}$, overlapping), 0.83-0.79 (m, $6 \mathrm{H}) \mathrm{ppm}$. ${ }^{13} \mathrm{C}$ NMR $(125 \mathrm{MHz}, \mathrm{CDCl} 3) \delta 156.23,146.13,137.77,137.61$, $129.65,128.63,127.65,126.99,126.62,79.99,73.98,72.94,67.85$, $54.72,53.57,39.01,35.79,28.37,23.11,22.83,10.65,10.42 \mathrm{ppm}$. HRMS (ESI) $m / z$ : $[\mathrm{M}+\mathrm{H}]^{+}$calcd for $\mathrm{C}_{29} \mathrm{H}_{45} \mathrm{~N}_{2} \mathrm{O}_{7} \mathrm{~S}$, 565.2942; found 565.2942 .

(3R,3aS,6aR)-Hexahydrofuro[2,3-b]furan-3-yl ((2S,3R)-4-((4-)((R)1,2-Dihydroxyethyl)- $N$-isobutylphenyl) sulfonamido)-3-hydroxy-1phenylbutan-2-yl)carbamate (22). A solution of compound 20a $(0.78 \mathrm{~g}, 1.45 \mathrm{mmol})$ in anhydrous dichloromethane $(5 \mathrm{~mL})$ was treated with a solution of $4 \mathrm{~N} \mathrm{HCl}$ in 1,4-dioxane $(10 \mathrm{~mL})$. After the reaction mixture was stirred at room temperature for $2.5 \mathrm{~h}$, solvents were evaporated under reduced pressure, and the residue was triturated with diethyl ether and dried under high vacuum. A solution of the deprotected amine salt in anhydrous acetonitrile $(15 \mathrm{~mL})$ was cooled to $0{ }^{\circ} \mathrm{C}$ and treated with diisopropylethylamine $(0.75 \mathrm{~g}, 5.813$ mmol) followed by bis-THF activated carbonate 11 (0.39 g, 1.45 $\mathrm{mmol})$. The resulting reaction mixture was stirred at room temperature for $24 \mathrm{~h}$. Solvents were evaporated under reduced pressure, and the residue was purified by automated flash chromatography using a silica gel column (RediSep Gold, $40 \mathrm{~g}$, gradient elution with $0-20 \%$ methanol/dichloromethane) to give compound $22(0.28 \mathrm{~g}, 33 \%)$ as a white solid. ${ }^{1} \mathrm{H}$ NMR $(500 \mathrm{MHz}$, $\left.\mathrm{CDCl}_{3}\right) \delta 7.76(\mathrm{~d}, J=8.3 \mathrm{~Hz}, 2 \mathrm{H}), 7.55(\mathrm{~d}, J=8.2 \mathrm{~Hz}, 2 \mathrm{H}), 7.30-$ $7.27(\mathrm{~m}, 2 \mathrm{H}), 7.22-7.20(\mathrm{~m}, 3 \mathrm{H}), 5.64(\mathrm{~d}, J=5.2 \mathrm{~Hz}, 1 \mathrm{H}), 4.99(\mathrm{q}$, $J=7.0 \mathrm{~Hz}, 1 \mathrm{H}), 4.93-4.89(\mathrm{~m}, 2 \mathrm{H}), 3.94(\mathrm{dd}, J=9.6,6.3 \mathrm{~Hz}, 1 \mathrm{H})$, 3.89-3.81 (m, $4 \mathrm{H}), 3.69-3.62(\mathrm{~m}, 3 \mathrm{H}), 3.56(\mathrm{br} \mathrm{s}, 1 \mathrm{H}), 3.16$ (dd, $J$ $=15.5,8.5 \mathrm{~Hz}, 1 \mathrm{H}), 3.08(\mathrm{dd}, J=13.5,3.0 \mathrm{~Hz}, 1 \mathrm{H}), 3.02-2.97(\mathrm{~m}$, $3 \mathrm{H}), 2.91-2.83(\mathrm{~m}, 2 \mathrm{H}), 2.79(\mathrm{dd}, J=13.5,9.0 \mathrm{~Hz}, 1 \mathrm{H}), 1.88-$ $1.81(\mathrm{~m}, 1 \mathrm{H}), 1.68-1.60(\mathrm{~m}, 1 \mathrm{H}), 1.49-1.46(\mathrm{~m}, 1 \mathrm{H}), 0.94(\mathrm{~d}, J=$ $6.6 \mathrm{~Hz}, 3 \mathrm{H}), 0.89(\mathrm{~d}, J=6.6 \mathrm{~Hz}, 3 \mathrm{H}) \mathrm{ppm} .{ }^{13} \mathrm{C}$ NMR $(100 \mathrm{MHz}$, $\left.\mathrm{CDCl}_{3}\right) \delta 155.61,146.12,137.59,129.48,128.74,127.68,127.08$, $126.79,109.44,73.93,73.62,72.89,71.04,69.78,67.83,59.04,55.24$, 53.92, 45.45, 35.80, 27.46, 26.00, 20.28, 20.00 ppm. HRMS (ESI) m/ $z:[\mathrm{M}+\mathrm{H}]^{+}$calcd for $\mathrm{C}_{29} \mathrm{H}_{41} \mathrm{~N}_{2} \mathrm{O}_{9} \mathrm{~S}, 593.2527$; found 593.2528. Anal. HPLC: $t_{\mathrm{R}} 9.69 \mathrm{~min}$, purity $99 \%$.

(3R,3aS,6aR)-Hexahydrofuro[2,3-b]furan-3-yl ((2S,3R)-4-((4-)((S)1,2-Dihydroxyethyl)- $N$-isobutylphenyl)sulfonamido)-3-hydroxy-1phenylbutan-2-yl)carbamate (23). The same procedure was used as described above for compound 22. Compound 21a (0.35 g, 0.652 $\mathrm{mmol}$ ) was treated with $4 \mathrm{~N} \mathrm{HCl}$ in 1,4-dioxane $(5 \mathrm{~mL})$, and the resulting amine salt was treated with diisopropylethylamine $(0.34 \mathrm{~g}$, $2.61 \mathrm{mmol})$ and bis-THF activated carbonate 11 ( $0.18 \mathrm{~g}, 0.652$ mmol) to give compound $23(0.34 \mathrm{~g}, 77 \%)$ as a white solid. ${ }^{1} \mathrm{H}$ NMR $\left(500 \mathrm{MHz}, \mathrm{CDCl}_{3}\right) \delta 7.77(\mathrm{~d}, J=8.3 \mathrm{~Hz}, 2 \mathrm{H}), 7.55(\mathrm{~d}, J=8.2 \mathrm{~Hz}, 2$
H), 7.30-7.27 (m, $2 \mathrm{H}), 7.23-7.20(\mathrm{~m}, 3 \mathrm{H}), 5.64(\mathrm{~d}, J=5.2 \mathrm{~Hz}, 1$ $\mathrm{H}), 4.99(\mathrm{q}, J=6.0 \mathrm{~Hz}, 1 \mathrm{H}), 4.92-4.87(\mathrm{~m}, 2 \mathrm{H}), 3.93(\mathrm{dd}, J=9.6$, 6.2 Hz, $1 \mathrm{H}), 3.88-3.81(\mathrm{~m}, 4 \mathrm{H}), 3.70-3.62(\mathrm{~m}, 3 \mathrm{H}), 3.54(\mathrm{br} \mathrm{s}, 1$ $\mathrm{H})$, 3.17-3.07 (m, $2 \mathrm{H}), 3.02-2.97(\mathrm{~m}, 3 \mathrm{H}), 2.92-2.74(\mathrm{~m}, 3 \mathrm{H})$, $2.15(\mathrm{br} \mathrm{s}, 1 \mathrm{H}), 1.88-1.82(\mathrm{~m}, 1 \mathrm{H}), 1.69-1.60(\mathrm{~m}, 1 \mathrm{H}), 1.52-1.48$ $(\mathrm{m}, 1 \mathrm{H}), 0.94(\mathrm{~d}, J=6.7 \mathrm{~Hz}, 3 \mathrm{H}), 0.90(\mathrm{~d}, J=6.6 \mathrm{~Hz}, 3 \mathrm{H}) \mathrm{ppm}$. ${ }^{13} \mathrm{C}$ NMR $\left(100 \mathrm{MHz}, \mathrm{CDCl}_{3}\right) \delta 155.60,146.15,137.56,129.48$, $128.75,127.70,127.5,126.80,109.46,73.91,73.63,72.89,71.10$, $69.79,67.85,59.12,55.22,53.99,45.43,35.87,27.47,26.02,20.28$ $20.00 \mathrm{ppm}$. HRMS (ESI) $\mathrm{m} / z:[\mathrm{M}+\mathrm{H}]^{+}$calcd for $\mathrm{C}_{29} \mathrm{H}_{41} \mathrm{~N}_{2} \mathrm{O}_{9} \mathrm{~S}$, 593.2527; found 593.2530. Anal. HPLC: $t_{\mathrm{R}} 9.85 \mathrm{~min}$, purity $98 \%$.

(3R,3aS,6aR)-Hexahydrofuro[2,3-b]furan-3-yl ((2S,3R)-4-((4-((R)1,2-Dihydroxyethyl)-N-((S)-2-methylbutyl)phenyl)sulfonamido)-3hydroxy-1-phenylbutan-2-yl)carbamate (24). The same procedure was used as described above for compound 22. Compound $20 \mathrm{~b}(0.52$ $\mathrm{g}, 0.944 \mathrm{mmol})$ was treated with $4 \mathrm{~N} \mathrm{HCl}$ in 1,4-dioxane $(8 \mathrm{~mL})$, and the resulting amine salt was treated with disopropylethylamine $(0.49$ g, $3.776 \mathrm{mmol})$ and bis-THF activated carbonate $11(0.26 \mathrm{~g}, 0.944$ $\mathrm{mmol})$ to give compound $24(0.40 \mathrm{~g}, 70 \%)$ as a white solid. ${ }^{1} \mathrm{H}$ NMR $\left(500 \mathrm{MHz}, \mathrm{CDCl}_{3}\right) \delta 7.76(\mathrm{~d}, J=8.1 \mathrm{~Hz}, 2 \mathrm{H}), 7.55(\mathrm{~d}, J=8.1 \mathrm{~Hz}, 2$ $\mathrm{H}), 7.30-7.27(\mathrm{~m}, 2 \mathrm{H}), 7.22-7.20(\mathrm{~m}, 3 \mathrm{H}), 5.64(\mathrm{~d}, J=5.1 \mathrm{~Hz}, 1$ $\mathrm{H}), 5.01(\mathrm{q}, J=6.5 \mathrm{~Hz}, 1 \mathrm{H}), 4.91-4.87(\mathrm{~m}, 2 \mathrm{H}), 3.94(\mathrm{dd}, J=9.5$, $6.5 \mathrm{~Hz}, 1 \mathrm{H}), 3.86-3.80(\mathrm{~m}, 4 \mathrm{H}), 3.70-3.62(\mathrm{~m}, 3 \mathrm{H}), 3.52(\mathrm{br} \mathrm{s}, 1$ $\mathrm{H}), 3.17-2.97(\mathrm{~m}, 4 \mathrm{H}), 3.91-2.97(\mathrm{~m}, 4 \mathrm{H}), 2.16(\mathrm{br} \mathrm{s}, 1 \mathrm{H}), 1.69-$ $1.47(\mathrm{~m}, 4 \mathrm{H}) 1.14-1.05(\mathrm{~m}, 1 \mathrm{H}), 0.88-0.86(\mathrm{~m}, 6 \mathrm{H}) \mathrm{ppm} .{ }^{13} \mathrm{C}$ NMR $\left(100 \mathrm{MHz}, \mathrm{CDCl}_{3}\right) \delta 155.63,146.40,137.66,137.34,129.44$, $128.65,127.60,127.05,126.70,109.43,73.90,73.51,72.77,71.13$, 69.77, 67.73, 57.32, 55.28, 53.59, 45.53, 35.81, 33.45, 26.61, 25.97, $17.02,11.23$ ppm. HRMS (ESI) $\mathrm{m} / z:[\mathrm{M}+\mathrm{H}]^{+}$calcd for $\mathrm{C}_{30} \mathrm{H}_{43} \mathrm{~N}_{2} \mathrm{O}_{9} \mathrm{~S}$, 607.2684; found 607.2687. Anal. HPLC: $t_{\mathrm{R}} 10.53$ min, purity $99 \%$.

$(3 R, 3 a S, 6 a R)-H e x a h y d r o f u r o[2,3-b] f u r a n-3-y l \quad((2 S, 3 R)-4-((4-((S)-$ 1,2-Dihydroxyethyl)- $N$-((S)-2-methylbutyl)phenyl)sulfonamido)-3hydroxy-1-phenylbutan-2-yl)carbamate (25). The same procedure was used as described above for compound 22. Compound 21b $(0.45$ g, $0.817 \mathrm{mmol}$ ) was treated with $4 \mathrm{~N} \mathrm{HCl}$ in 1,4-dioxane $(8 \mathrm{~mL})$, and the resulting amine salt was treated with diisopropylethylamine $(0.42$ g, $3.27 \mathrm{mmol})$ and bis-THF activated carbonate $11(0.22 \mathrm{~g}, 0.817$ $\mathrm{mmol})$ to give compound $25(0.39 \mathrm{~g}, 79 \%)$ as a white solid. ${ }^{1} \mathrm{H}$ NMR $\left(400 \mathrm{MHz}, \mathrm{CDCl}_{3}\right) \delta 7.76(\mathrm{~d}, J=8.3 \mathrm{~Hz}, 2 \mathrm{H}), 7.55(\mathrm{~d}, J=8.3 \mathrm{~Hz}, 2$ H), 7.30-7.27 (m, $2 \mathrm{H}), 7.23-7.20(\mathrm{~m}, 3 \mathrm{H}), 5.64(\mathrm{~d}, J=5.2 \mathrm{~Hz}, 1$ $\mathrm{H}), 4.99(\mathrm{q}, J=6.0 \mathrm{~Hz} 1 \mathrm{H}), 4.91-4.87(\mathrm{~m}, 2 \mathrm{H}), 3.93(\mathrm{dd}, J=9.5$, $6.0 \mathrm{~Hz}, 1 \mathrm{H}), 3.87-3.81(\mathrm{~m}, 4 \mathrm{H}), 3.71-3.62(\mathrm{~m}, 3 \mathrm{H}), 3.50(\mathrm{br} \mathrm{s}, 1$ $\mathrm{H}), 3.15-2.97(\mathrm{~m}, 5 \mathrm{H}), 2.92-2.78(\mathrm{~m}, 3 \mathrm{H}), 1.70-1.45(\mathrm{~m}, 4 \mathrm{H})$, $1.14-1.05(\mathrm{~m}, 1 \mathrm{H}), 0.88-0.85(\mathrm{~m}, 6 \mathrm{H}) \mathrm{ppm} .{ }^{13} \mathrm{C}$ NMR $(100 \mathrm{MHz}$, $\left.\mathrm{CDCl}_{3}\right) \delta 155.63,146.44,137.66,137.28,129.45,128.65,127.62$, $127.03,126.70,109.44,73.88,73.51,72.78,71.19,69.78,67.74,57.38$, $55.28,53.63,45.52,35.86,33.46,26.63,25.98,17.02,11.23 \mathrm{ppm}$. HRMS (ESI) $m / z$ : $[\mathrm{M}+\mathrm{H}]^{+}$calcd for $\mathrm{C}_{30} \mathrm{H}_{43} \mathrm{~N}_{2} \mathrm{O}_{9} \mathrm{~S}$, 607.2684; found 607.2687. Anal. HPLC: $t_{\mathrm{R}} 10.39 \mathrm{~min}$, purity $97 \%$.

$(3 R, 3 a S, 6 a R)$-Hexahydrofuro[2,3-b]furan-3-yl ((2S,3R)-4-((4-((R)1,2-Dihydroxyethyl)-N-(2-ethylbutyl)phenyl)sulfonamido)-3-hydroxy-1-phenylbutan-2-yl)carbamate (26). The same procedure was used as described above for compound 22. Compound 20c $(0.51$ $\mathrm{g}, 0.903 \mathrm{mmol})$ was treated with $4 \mathrm{~N} \mathrm{HCl}$ in 1,4-dioxane $(8 \mathrm{~mL})$, and the resulting amine salt was treated with diisopropylethylamine $(0.47$ $\mathrm{g}, 3.61 \mathrm{mmol})$ and bis-THF activated carbonate $11(0.24 \mathrm{~g}, 0.903$ $\mathrm{mmol})$ to give compound $26(0.31 \mathrm{~g}, 64 \%)$ as a white solid. ${ }^{1} \mathrm{H}$ NMR $\left(500 \mathrm{MHz}, \mathrm{CDCl}_{3}\right) \delta 7.77(\mathrm{~d}, J=8.3 \mathrm{~Hz}, 2 \mathrm{H}), 7.55(\mathrm{~d}, J=8.2 \mathrm{~Hz}, 2$ H), 7.30-7.27 (m, $2 \mathrm{H}), 7.22-7.20(\mathrm{~m}, 3 \mathrm{H}), 5.64(\mathrm{~d}, J=5.2 \mathrm{~Hz}, 1$ $\mathrm{H}), 5.00(\mathrm{q}, J=6.5 \mathrm{~Hz}, 1 \mathrm{H}), 4.90(\mathrm{dd}, J=7.8,3.4 \mathrm{~Hz}, 1 \mathrm{H}), 4.86(\mathrm{~d}$ $J=9.0 \mathrm{~Hz}, 1 \mathrm{H}), 3.93(\mathrm{dd}, J=9.7,6.3 \mathrm{~Hz}, 1 \mathrm{H}), 3.87-3.78(\mathrm{~m}, 4 \mathrm{H})$, $3.69-3.62(\mathrm{~m}, 4 \mathrm{H}), 3.16-3.04(\mathrm{~m}, 3 \mathrm{H}), 2.98(\mathrm{~d}, J=15.0 \mathrm{~Hz}, 1 \mathrm{H})$, $2.91-2.87(\mathrm{~m}, 2 \mathrm{H}), 2.80(\mathrm{dd}, J=14.1,9.3 \mathrm{~Hz}, 1 \mathrm{H}), 1.68-1.60(\mathrm{~m}$, $1 \mathrm{H}), 1.50-1.39(\mathrm{~m}, 3 \mathrm{H}), 1.35-1.25(\mathrm{~m}, 3 \mathrm{H}), 0.85-0.81(\mathrm{~m}, 6 \mathrm{H})$ ppm. ${ }^{13} \mathrm{C}$ NMR $\left(100 \mathrm{MHz}, \mathrm{CDCl}_{3}\right) \delta 155.62,146.38,137.64,137.22$, $129.45,128.67,127.65,127.08,126.72,109.43,73.92,73.54,73.11$, $71.05,69.77,67.76,55.23,54.85,53.68,45.51,39.05,35.91,25.96$, 23.06, 22.84, 10.65, 10.45 ppm. HRMS (ESI) $m / z:[\mathrm{M}+\mathrm{H}]^{+}$calcd 
for $\mathrm{C}_{31} \mathrm{H}_{45} \mathrm{~N}_{2} \mathrm{O}_{9} \mathrm{~S}$, 621.2840; found 621.284. Anal. HPLC: $t_{\mathrm{R}} 11.11$ min, purity $97 \%$.

(3R,3aS,6aR)-Hexahydrofuro[2,3-b]furan-3-yl ((2S,3R)-4-((4-((S)1,2-Dihydroxyethyl)- $N$-(2-ethylbutyl)phenyl) sulfonamido)-3-hydroxy-1-phenylbutan-2-yl)carbamate (27). The same procedure was used as described above for compound 22. Compound 21c ( 0.50 $\mathrm{g}, 0.885 \mathrm{mmol})$ was treated with $4 \mathrm{~N} \mathrm{HCl}$ in dioxane $(10 \mathrm{~mL})$, and the resulting amine salt was treated with diisopropylethylamine $(0.46$ g, $3.54 \mathrm{mmol})$ and bis-THF activated carbonate $11(0.24 \mathrm{~g}, 0.885$ mmol $)$ to give compound $27(0.31 \mathrm{~g}, 57 \%)$ as a white solid. ${ }^{1} \mathrm{H}$ NMR $\left(400 \mathrm{MHz}, \mathrm{CDCl}_{3}\right) \delta 7.77(\mathrm{~d}, J=8.3 \mathrm{~Hz}, 2 \mathrm{H}), 7.56(\mathrm{~d}, J=8.2 \mathrm{~Hz}, 2$ H), 7.30-7.27 (m, $2 \mathrm{H}), 7.22-7.20(\mathrm{~m}, 3 \mathrm{H}), 5.64(\mathrm{~d}, J=5.2 \mathrm{~Hz}, 1$ $\mathrm{H}), 5.01-4.99(\mathrm{q}, \mathrm{J}=6.0 \mathrm{~Hz}, 1 \mathrm{H}), 4.91(\mathrm{~d}, J=7.0 \mathrm{~Hz}, 1 \mathrm{H}), 4.83(\mathrm{~d}$, $J=9.0 \mathrm{~Hz}, 1 \mathrm{H}), 3.92(\mathrm{dd}, J=9.6,6.2 \mathrm{~Hz}, 1 \mathrm{H}), 3.88-3.80(\mathrm{~m}, 4 \mathrm{H})$, 3.70-3.60 (m, $4 \mathrm{H}), 3.15-3.05(\mathrm{~m}, 3 \mathrm{H}), 2.99(\mathrm{~d}, J=15.0,2.0 \mathrm{~Hz}, 1$ H), 2.92-2.89 (m, $2 \mathrm{H}), 2.80(\mathrm{dd}, J=14.1,9.2 \mathrm{~Hz}, 1 \mathrm{H}), 2.12(\mathrm{br} \mathrm{s}, 1$ $\mathrm{H}), 1.69-1.61(\mathrm{~m}, 1 \mathrm{H}), 1.51-1.39(\mathrm{~m}, 3 \mathrm{H}), 1.35-1.28(\mathrm{~m}, 3 \mathrm{H})$, $0.85-0.81(\mathrm{~m}, 6 \mathrm{H}) \mathrm{ppm} .{ }^{13} \mathrm{C}$ NMR $\left(100 \mathrm{MHz}, \mathrm{CDCl}_{3}\right) \delta 155.59$, $146.18,137.52,137.28,129.49,128.75,127.74,127.06,126.80$, $109.45,73.92,73.63,73.13,71.05,69.78,67.84,55.12,53.95,45.44$, $39.24,36.00,26.00,23.14,22.87,10.73,10.45 \mathrm{ppm}$. HRMS (ESI) $\mathrm{m} /$ $z:[\mathrm{M}+\mathrm{H}]^{+}$calcd for $\mathrm{C}_{31} \mathrm{H}_{45} \mathrm{~N}_{2} \mathrm{O}_{9} \mathrm{~S}, 621.2840$; found 621.2847. Anal. HPLC: $t_{\mathrm{R}} 11.15$ min, purity $99 \%$.

Antiviral Assays. 293T and TZM-BL ${ }^{36}$ cells (NIH AIDS Research and Reference Reagent Program) were maintained in Dulbecco's modified Eagle's medium supplemented with $10 \%$ fetal calf serum in the presence of penicillin and streptomycin at $37^{\circ} \mathrm{C}$ with $5 \% \mathrm{CO}_{2}$. To determine the concentration of drugs achieving $50 \%$ inhibition of infection compared with the drug-free control, $4.5 \times 10^{6}$ $293 \mathrm{~T}$ cells were seeded onto a $10-\mathrm{cm}$ plate $24 \mathrm{~h}$ before transfection. Cells were transfected with $8 \mu \mathrm{g}$ of either the wild-type plasmid, infectious molecular clone pNL-CH derived from the pNL4-3 clone of HIV-1, or each PI-resistant HIV-1 variant ${ }^{34}$ using FuGENE 6 transfection reagent (Roche). The culture supernatant of $293 \mathrm{~T}$ cells transfected with wild-type or PI-resistant HIV-1 variant was removed $18 \mathrm{~h}$ after transfection, and the cells were washed with $1 \times$ PBS. The $293 \mathrm{~T}$ cells were collected and transferred to wells of a 24-well plate. Briefly, each drug was serially diluted in the culture medium, and the dilutions were added to the wells of a 24-well plate. The $293 \mathrm{~T}$ cells $\left(0.5 \times 10^{6}\right.$ per well $)$ collected from the transfection were added to wells containing various concentrations of drug. The culture supernatant containing virus particles was harvested $18 \mathrm{~h}$ after the $293 \mathrm{~T}$ cells were reseeded in the presence of drug. This supernatant was filtered through a $0.45-\mu \mathrm{m}$-pore-size membrane (Millipore) to remove cell debris and then used to infect $2 \times 10^{4} \mathrm{TZM}-\mathrm{BL}$ cells in a 96-well plate following a procedure previously described. ${ }^{37}$ The culture supernatant was removed from each well $48 \mathrm{~h}$ postinfection, and the cells were washed with $1 \times$ PBS. For the luciferase assay, infected TZM-BL cells were lysed in $1 \times$ reporter lysis buffer (Promega) and the cells were kept at $-80{ }^{\circ} \mathrm{C}$. After one freeze-thaw cycle, the cell lysates were transferred into a 96-well assay plate (Costar), and luciferase activity was measured using a luminometer (Promega). The culture supernatant harvested from 293T cells reseeded in the absence of drugs was used as a drug-free control. $\mathrm{EC}_{50}$ was determined based on a dose-response curve generated using GraphPad Prism (version 7.0).

Protease Gene Construction. Protease gene construction was carried out as previously described. ${ }^{38,39}$ The NL4-3 strain has four naturally occurring polymorphisms in the protease relative to the SF2 strain. ${ }^{40}$ In short, the protease variant genes (I84V, I50V/A71V) were constructed using QuikChange site-directed mutagenesis (Genewiz) onto NL4-3 wild-type protease on a pET11a plasmid with codon optimization for protein expression in Escherichia coli. A Q7K mutation was included to prevent autoproteolysis. ${ }^{41}$

Protein Expression and Purification. The expression, isolation, and purification of WT and mutant HIV-1 proteases used for the kinetic assays and crystallization were carried out as previously described. $^{38,39}$ Briefly, the gene encoding the HIV protease was subcloned into the heat-inducible pXC35 expression vector (ATCC) and transformed into E. coli TAP-106 cells. Cells grown in $6 \mathrm{~L}$ of
Terrific Broth were lysed with a cell disruptor, and the protein was purified from inclusion bodies. ${ }^{42}$ The inclusion body centrifugation pellet was dissolved in 50\% acetic acid followed by another round of centrifugation to remove impurities. Size exclusion chromatography was used to separate high molecular weight proteins from the desired protease. This was carried out on a 2.1 L Sephadex G-75 superfine column (Millipore Sigma) equilibrated with 50\% acetic acid. The cleanest fractions of HIV protease were refolded into a 10 -fold dilution of $0.05 \mathrm{M}$ sodium acetate at $\mathrm{pH} 5.5$, 5\% ethylene glycol, $10 \%$ glycerol, and $5 \mathrm{mM}$ DTT. Folded protein was concentrated down to $0.7-2 \mathrm{mg} / \mathrm{mL}$ and stored. This stored protease was used in $K_{m}$ and $K_{i}$ assays. For crystallography, a final purification was performed with a Pharmacia Superdex 75 FPLC column equilibrated with $0.05 \mathrm{M}$ sodium acetate at $\mathrm{pH} 5.5,5 \%$ ethylene glycol, $10 \%$ glycerol, and 5 $\mathrm{mM}$ DTT. Protease fractions purified from the size exclusion column were concentrated to $1-2 \mathrm{mg} / \mathrm{mL}$ using an Amicon Ultra-15 $10-\mathrm{kDa}$ device (Millipore) for crystallization.

Enzyme Inhibition Assays. The $K_{m}$ and $K_{i}$ assays were carried out as previously described. ${ }^{31,43}$ In the $K_{m}$ assay, a 10-amino acid substrate containing the natural MA/CA cleavage site with an EDANS/DABCYL FRET pair was dissolved in 8\% DMSO at $40 \mathrm{nM}$ and $6 \%$ DMSO at $30 \mathrm{nM}$. The $30 \mathrm{nM}$ of substrate was $4 / 5$ th serially diluted from $30 \mathrm{nM}$ to $6 \mathrm{nM}$, including a $0 \mathrm{nM}$ control. HIV protease was diluted to $120 \mathrm{nM}$ and, using a PerkinElmer Envision plate reader, $5 \mu \mathrm{L}$ was added to the 96-well plate to obtain a final concentration of $10 \mathrm{nM}$. The fluorescence was observed with an excitation at $340 \mathrm{~nm}$ and emission at $492 \mathrm{~nm}$ and monitored for 200 counts, for approximately $23 \mathrm{~min}$. FRET inner filter effect correction was applied as previously described. ${ }^{44}$ Corrected data were analyzed with Prism7.

To determine the enzyme inhibition constant $\left(K_{i}\right)$, in a 96-well plate, each inhibitor was $2 / 3$ serially diluted from $3 \mathrm{nM}$ to $52 \mathrm{pM}$, including a $0 \mathrm{pM}$ control, and incubated with $0.35 \mathrm{nM}$ protein for $1 \mathrm{~h}$. A 10-amino acid substrate containing an optimized protease cleavage site with an EDANS/DABCYL FRET pair was dissolved in $4 \%$ DMSO at $120 \mu \mathrm{M}$. Using the Envision plate reader, $5 \mu \mathrm{L}$ of the 120 $\mu \mathrm{M}$ substrate was added to the 96-well plate to a final concentration of $10 \mu \mathrm{M}$. The fluorescence was observed with an excitation at 340 $\mathrm{nm}$ and emission at $492 \mathrm{~nm}$ and monitored for 200 counts, for approximately $60 \mathrm{~min}$. Data was analyzed with Prism7.

Protein Crystallization. The condition reliably producing cocrystals of NL4-3 WT protease bound to PIs was discovered and optimized as previously described. ${ }^{45}$ Briefly, all cocrystals were grown at room temperature by a hanging drop vapor diffusion method in 24well VDX hanging-drop trays (Hampton Research) with a protease concentration of $1.0-1.7 \mathrm{mg} / \mathrm{mL}$ with 3 -fold molar excess of inhibitors. Crystallization drops of $1 \mu \mathrm{L}$ of protein-inhibitor solution and $2 \mu \mathrm{L}$ of reservoir solution consisted of $22-26 \%(\mathrm{w} / \mathrm{v})$ ammonium sulfate with $0.1 \mathrm{M}$ bis-Tris-methane buffer at $\mathrm{pH}$ 5.5. Drops were microseeded with a cat whisker. Diffraction quality crystals were obtained within 1 week. As data were collected at $100 \mathrm{~K}$, cryogenic conditions contained the precipitant solution supplemented with $25 \%$ glycerol.

X-ray Data Collection and Structure Solution. X-ray diffraction data were collected and solved as previously described. ${ }^{39,45,46}$ Diffraction quality crystals were flash frozen under a cryostream when mounting the crystal at our in-house Rigaku_Saturn944 X-ray system. The cocrystal diffraction intensities were indexed, integrated, and scaled using HKL3000. ${ }^{47}$ Structures were solved using molecular replacement with PHASER. ${ }^{48}$ Model building and refinement were performed using $\operatorname{Coot}^{49}$ and Phenix. ${ }^{50}$ Ligands were designed in Maestro, and the output sdf files were used in the Phenix program eLBOW ${ }^{51}$ to generate cif files containing atomic positions and constraints necessary for ligand refinement. Iterative rounds of crystallographic refinement were carried out until convergence was achieved. To limit bias throughout the refinement process, five percent of the data were reserved for the free $\mathrm{R}$-value calculation. ${ }^{52}$ MolProbity ${ }^{53}$ was applied to evaluate the final structures before deposition in the PDB. Structure analysis, superposition, and figure generation was done using PyMOL. ${ }^{54} \mathrm{X}$-ray data collection and 
crystallographic refinement statistics are presented in the Supporting Information (Table S2).

Molecular Modeling. Molecular modeling was carried out using MacroModel (Schrödinger, LLC, New York, NY) ${ }^{55}$ Briefly, inhibitors were modeled into the active site of wild-type HIV-1 protease using the protease- 3 and protease- 4 cocomplex structures (PDB codes: $3 \mathrm{O} 9 \mathrm{~B}$ and $3 \mathrm{O} 9 \mathrm{G}) .^{23}$ Structures were prepared using the Protein Preparation tool in Maestro 11 (Schrödinger, LLC, New York, NY). ${ }^{55}$ $2 \mathrm{D}$ chemical structures were modified with the appropriate changes using the Build tool in Maestro. Once modeled, molecular energy minimizations were performed for each inhibitor-protease complex using the PRCG method with 2500 maximum iterations and 0.05 gradient convergence threshold. PDB files of modeled complexes were generated in Maestro for structural analysis.

\section{ASSOCIATED CONTENT}

\section{S Supporting Information}

The Supporting Information is available free of charge on the ACS Publications website at DOI: 10.1021/acs.jmedchem.9b00838.

Synthesis and analytical data of intermediate compounds, Figures S1-S5, Tables S1-S3 (PDF)

Molecular formula strings (CSV)

\section{Accession Codes}

The PDB accession codes for X-ray crystal structures of WT HIV-1 protease in complex with DRV and inhibitors 2-4, 1217, and 22-27 are 6DGX, 6OXO, 6OXP, 6OXQ 6OXR, 6OXS, 6OXT, 6OXU, 6OXV, 6OXW, 6OXX, 6OXY, 6OXZ, $6 \mathrm{OY} 0,6 \mathrm{OY} 1$, and 6OY2. The authors will release the atomic coordinates and experimental data upon article publication.

\section{AUTHOR INFORMATION}

\section{Corresponding Authors}

*Akbar Ali: Phone: +1 508856 8873; Fax: +1 508856 6464; E-mail: Akbar.Ali@umassmed.edu.

*Celia A. Schiffer: Phone: +1 508856 8008; Fax: +1 508856 6464; E-mail: Celia.Schiffer@umassmed.edu.

ORCID $\odot$

Gordon J. Lockbaum: 0000-0003-2720-6984

Nese Kurt Yilmaz: 0000-0002-5036-676X

Celia A. Schiffer: 0000-0003-2270-6613

Akbar Ali: 0000-0003-3491-791X

\section{Author Contributions}

${ }^{\S}$ L.N.R. and G.J.L. contributed equally to this work.

Notes

The authors declare no competing financial interest.

\section{ACKNOWLEDGMENTS}

This work was supported by a grant from the National Institute of General Medical Sciences of the NIH (P01 GM109767). We thank Kaneka USA for generous gifts of chiral epoxides, Ellen A. Nalivaika for providing the HIV-1 protease variants, the AIDS Research and Reference Reagent Program (NIAD, NIH) for reference protease inhibitors, and William Royer, Brian Kelch, and members of the Schiffer and Miller laboratories for helpful discussions.

\section{ABBREVIATIONS USED}

HIV-1, human immunodeficiency virus type 1; AIDS, acquired immunodeficiency syndrome; bis-THF, bis-tetrahydrofuran; Boc, tert-butoxycarbonyl; DRV, darunavir; FRET, fluorescence resonance energy transfer; MDR, multidrug-resistant; PIs, protease inhibitors; SAR, structure-activity relationships; TFA, trifluoroacetic acid; THF, tetrahydrofuran; TLC, thin layer chromatography

\section{REFERENCES}

(1) Ghosh, A. K.; Osswald, H. L.; Prato, G. Recent progress in the development of HIV-1 protease inhibitors for the treatment of HIV/ AIDS. J. Med. Chem. 2016, 59, 5172-5208.

(2) Ali, A.; Bandaranayake, R. M.; Cai, Y.; King, N. M.; Kolli, M.; Mittal, S.; Murzycki, J. F.; Nalam, M. N.; Nalivaika, E. A.; Ozen, A.; Prabu-Jeyabalan, M. M.; Thayer, K.; Schiffer, C. A. Molecular basis for drug resistance in HIV-1 protease. Viruses 2010, 2, 2509-2535.

(3) Shen, L.; Peterson, S.; Sedaghat, A. R.; McMahon, M. A.; Callender, M.; Zhang, H.; Zhou, Y.; Pitt, E.; Anderson, K. S.; Acosta, E. P.; Siliciano, R. F. Dose-response curve slope sets class-specific limits on inhibitory potential of anti-HIV drugs. Nat. Med. 2008, 14, $762-766$.

(4) Sampah, M. E.; Shen, L.; Jilek, B. L.; Siliciano, R. F. Doseresponse curve slope is a missing dimension in the analysis of HIV-1 drug resistance. Proc. Natl. Acad. Sci. U. S. A. 2011, 108, 7613-7618.

(5) Cihlar, T.; Fordyce, M. Current status and prospects of HIV treatment. Curr. Opin. Virol. 2016, 18, 50-56.

(6) Panel on Antiretroviral Guidelines for Adults and Adolescents. Guidelines for the Use of Antiretroviral Agents in Adults and Adolescents with HIV; Department of Health and Human Services. Available at http://aidsinfo.nih.gov/contentfiles/lvguidelines / AdultandAdolescentGL.pdf. (Accessed May 20, 2019).

(7) El Bouzidi, K.; White, E.; Mbisa, J. L.; Sabin, C. A.; Phillips, A. N.; Mackie, N.; Pozniak, A. L.; Tostevin, A.; Pillay, D.; Dunn, D. T. HIV-1 drug resistance mutations emerging on darunavir therapy in PI-naive and -experienced patients in the UK. J. Antimicrob. Chemother. 2016, 71, 3487-3494.

(8) Stockdale, A. J.; Saunders, M. J.; Boyd, M. A.; Bonnett, L. J.; Johnston, V.; Wandeler, G.; Schoffelen, A. F.; Ciaffi, L.; Stafford, K.; Collier, A. C.; Paton, N. I.; Geretti, A. M. Effectiveness of protease inhibitor/nucleos $(\mathrm{t})$ ide reverse transcriptase inhibitor-based secondline antiretroviral therapy for the treatment of human immunodeficiency virus type 1 infection in sub-Saharan Africa: a systematic review and meta-analysis. Clin. Infect. Dis. 2018, 66, 1846-1857.

(9) Shafer, R. W. Human immunodeficiency virus type 1 drug resistance mutations update. J. Infect. Dis. 2017, 216, S843-S846.

(10) Wensing, A. M.; Calvez, V.; Gunthard, H. F.; Johnson, V. A.; Paredes, R.; Pillay, D.; Shafer, R. W.; Richman, D. D. 2017 Update of the drug resistance mutations in HIV-1. Top. Antivir. Med. 2017, 24, 132-133.

(11) Gunthard, H. F.; Calvez, V.; Paredes, R.; Pillay, D.; Shafer, R. W.; Wensing, A. M.; Jacobsen, D. M.; Richman, D. D. Human immunodeficiency virus drug resistance: 2018 recommendations of the international antiviral society-USA panel. Clin. Infect. Dis. 2019, $68,177-187$

(12) Saag, M. S.; Benson, C. A.; Gandhi, R. T.; Hoy, J. F.; Landovitz, R. J.; Mugavero, M. J.; Sax, P. E.; Smith, D. M.; Thompson, M. A.; Buchbinder, S. P.; Del Rio, C.; Eron, J. J., Jr.; Fatkenheuer, G.; Gunthard, H. F.; Molina, J. M.; Jacobsen, D. M.; Volberding, P. A. Antiretroviral drugs for treatment and prevention of HIV infection in adults: 2018 recommendations of the international antiviral societyUSA panel. JAMA 2018, 320, 379-396.

(13) Ghosh, A. K.; Chapsal, B. D.; Weber, I. T.; Mitsuya, H. Design of HIV protease inhibitors targeting protein backbone: an effective strategy for combating drug resistance. Acc. Chem. Res. 2008, 41, 7886.

(14) Surleraux, D. L.; Tahri, A.; Verschueren, W. G.; Pille, G. M.; de Kock, H. A.; Jonckers, T. H.; Peeters, A.; De Meyer, S.; Azijn, H.; Pauwels, R.; de Bethune, M. P.; King, N. M.; Prabu-Jeyabalan, M.; Schiffer, C. A.; Wigerinck, P. B. Discovery and selection of TMC114, a next generation HIV-1 protease inhibitor. J. Med. Chem. 2005, 48, $1813-1822$ 
(15) Tie, Y.; Boross, P. I.; Wang, Y. F.; Gaddis, L.; Hussain, A. K.; Leshchenko, S.; Ghosh, A. K.; Louis, J. M.; Harrison, R. W.; Weber, I. T. High resolution crystal structures of HIV-1 protease with a potent non-peptide inhibitor (UIC-94017) active against multi-drug-resistant clinical strains. J. Mol. Biol. 2004, 338, 341-352.

(16) Ghosh, A. K.; Rao, K. V.; Nyalapatla, P. R.; Osswald, H. L.; Martyr, C. D.; Aoki, M.; Hayashi, H.; Agniswamy, J.; Wang, Y. F.; Bulut, H.; Das, D.; Weber, I. T.; Mitsuya, H. Design and development of highly potent HIV-1 protease inhibitors with a crown-like oxotricyclic core as the P2-ligand to combat multidrug-resistant HIV variants. J. Med. Chem. 2017, 60, 4267-4278.

(17) Ghosh, A. K.; P, R. N.; Kovela, S.; Rao, K. V.; Brindisi, M.; Osswald, H. L.; Amano, M.; Aoki, M.; Agniswamy, J.; Wang, Y. F.; Weber, I. T.; Mitsuya, H. Design and synthesis of highly potent HIV-1 protease inhibitors containing tricyclic fused ring systems as novel P2 ligands: structure-activity studies, biological and X-ray structural analysis. J. Med. Chem. 2018, 61, 4561-4577.

(18) Ghosh, A. K.; Rao, K. V.; Nyalapatla, P. R.; Kovela, S.; Brindisi, M.; Osswald, H. L.; Sekhara Reddy, B.; Agniswamy, J.; Wang, Y. F.; Aoki, M.; Hattori, S. I.; Weber, I. T.; Mitsuya, H. Design of highly potent, dual-acting and central-nervous-system-penetrating HIV-1 protease inhibitors with excellent potency against multidrug-resistant HIV-1 variants. ChemMedChem 2018, 13, 803-815.

(19) Aoki, M.; Hayashi, H.; Rao, K. V.; Das, D.; Higashi-Kuwata, N.; Bulut, H.; Aoki-Ogata, H.; Takamatsu, Y.; Yedidi, R. S.; Davis, D. A.; Hattori, S. I.; Nishida, N.; Hasegawa, K.; Takamune, N.; Nyalapatla, P. R.; Osswald, H. L.; Jono, H.; Saito, H.; Yarchoan, R.; Misumi, S.; Ghosh, A. K.; Mitsuya, H. A novel central nervous system-penetrating protease inhibitor overcomes human immunodeficiency virus 1 resistance with unprecedented aM to pM potency. Elife 2017, 6, No. e28020.

(20) King, N. M.; Prabu-Jeyabalan, M.; Nalivaika, E. A.; Schiffer, C. A. Combating susceptibility to drug resistance: lessons from HIV-1 protease. Chem. Biol. 2004, 11, 1333-1338.

(21) Altman, M. D.; Ali, A.; Reddy, G. S.; Nalam, M. N.; Anjum, S. G.; Cao, H.; Chellappan, S.; Kairys, V.; Fernandes, M. X.; Gilson, M. K.; Schiffer, C. A.; Rana, T. M.; Tidor, B. HIV-1 protease inhibitors from inverse design in the substrate envelope exhibit subnanomolar binding to drug-resistant variants. J. Am. Chem. Soc. 2008, 130, 60996113

(22) Kurt Yilmaz, N.; Swanstrom, R.; Schiffer, C. A. Improving viral protease inhibitors to counter drug resistance. Trends Microbiol. 2016, 24, 547-557.

(23) Nalam, M. N.; Ali, A.; Reddy, G. S.; Cao, H.; Anjum, S. G.; Altman, M. D.; Yilmaz, N. K.; Tidor, B.; Rana, T. M.; Schiffer, C. A. Substrate envelope-designed potent HIV-1 protease inhibitors to avoid drug resistance. Chem. Biol. 2013, 20, 1116-1124.

(24) Paulsen, J. L.; Leidner, F.; Ragland, D. A.; Kurt Yilmaz, N.; Schiffer, C. A. Interdependence of inhibitor recognition in HIV-1 protease. J. Chem. Theory Comput. 2017, 13, 2300-2309.

(25) Surleraux, D. L.; de Kock, H. A.; Verschueren, W. G.; Pille, G. M.; Maes, L. J.; Peeters, A.; Vendeville, S.; De Meyer, S.; Azijn, H.; Pauwels, R.; de Bethune, M. P.; King, N. M.; Prabu-Jeyabalan, M.; Schiffer, C. A.; Wigerinck, P. B. Design of HIV-1 protease inhibitors active on multidrug-resistant virus. J. Med. Chem. 2005, 48, 19651973.

(26) Amano, M.; Koh, Y.; Das, D.; Li, J.; Leschenko, S.; Wang, Y. F.; Boross, P. I.; Weber, I. T.; Ghosh, A. K.; Mitsuya, H. A novel bistetrahydrofuranylurethane-containing nonpeptidic protease inhibitor (PI), GRL-98065, is potent against multiple-PI-resistant human immunodeficiency virus in vitro. Antimicrob. Agents Chemother. 2007, 51, 2143-2155.

(27) Windsor, I. W.; Palte, M. J.; Lukesh, J. C., 3rd; Gold, B.; Forest, K. T.; Raines, R. T. Sub-picomolar inhibition of HIV-1 protease with a boronic acid. J. Am. Chem. Soc. 2018, 140, 14015-14018.

(28) Corey, E. J.; Bakshi, R. K.; Shibata, S. Highly enantioselective borane reduction of ketones catalyzed by chiral oxazaborolidines. Mechanism and synthetic implications. J. Am. Chem. Soc. 1987, 109, $5551-5553$.
(29) Sharpless, K. B.; Amberg, W.; Bennani, Y. L.; Crispino, G. A.; Hartung, J.; Jeong, K. S.; Kwong, H. L.; Morikawa, K.; Wang, Z. M. The osmium-catalyzed asymmetric dihydroxylation: a new ligand class and a process improvement. J. Org. Chem. 1992, 57, 2768-2771.

(30) Szermerski, M.; Melesina, J.; Wichapong, K.; Loppenberg, M.; Jose, J.; Sippl, W.; Holl, R. Synthesis, biological evaluation and molecular docking studies of benzyloxyacetohydroxamic acids as LpxC inhibitors. Bioorg. Med. Chem. 2014, 22, 1016-1628.

(31) Windsor, I. W.; Raines, R. T. Fluorogenic assay for inhibitors of HIV-1 protease with sub-picomolar affinity. Sci. Rep. 2015, 5, 11286.

(32) Ghosh, A. K., Ed. Aspartic Acid Proteases as Therapeutic Targets; Wiley-VCH: Weinheim, Germany, 2010.

(33) Ghosh, A. K.; Fyvie, W. S.; Brindisi, M.; Steffey, M.; Agniswamy, J.; Wang, Y. F.; Aoki, M.; Amano, M.; Weber, I. T.; Mitsuya, $\mathrm{H}$. Design, synthesis, biological evaluation, and X-ray studies of HIV-1 protease inhibitors with modified $\mathrm{P} 2$ ' ligands of darunavir. ChemMedChem 2017, 12, 1942-1952.

(34) Varghese, V.; Mitsuya, Y.; Fessel, W. J.; Liu, T. F.; Melikian, G. L.; Katzenstein, D. A.; Schiffer, C. A.; Holmes, S. P.; Shafer, R. W. Prototypical recombinant multi-protease-inhibitor-resistant infectious molecular clones of human immunodeficiency virus type 1 . Antimicrob. Agents Chemother. 2013, 57, 4290-4299.

(35) Miller, J. F.; Andrews, C. W.; Brieger, M.; Furfine, E. S.; Hale, M. R.; Hanlon, M. H.; Hazen, R. J.; Kaldor, I.; McLean, E. W.; Reynolds, D.; Sammond, D. M.; Spaltenstein, A.; Tung, R.; Turner, E. M.; Xu, R. X.; Sherrill, R. G. Ultra-potent P1 modified arylsulfonamide HIV protease inhibitors: the discovery of GW0385. Bioorg. Med. Chem. Lett. 2006, 16, 1788-1794.

(36) Wei, X.; Decker, J. M.; Liu, H.; Zhang, Z.; Arani, R. B.; Kilby, J. M.; Saag, M. S.; Wu, X.; Shaw, G. M.; Kappes, J. C. Emergence of resistant human immunodeficiency virus type 1 in patients receiving fusion inhibitor (T-20) monotherapy. Antimicrob. Agents Chemother. 2002, 46, 1896-1905.

(37) Lee, S. K.; Harris, J.; Swanstrom, R. A strongly transdominant mutation in the human immunodeficiency virus type 1 gag gene defines an Achilles heel in the virus life cycle. J. Virol. 2009, 83, 85368543.

(38) King, N. M.; Melnick, L.; Prabu-Jeyabalan, M.; Nalivaika, E. A.; Yang, S. S.; Gao, Y.; Nie, X.; Zepp, C.; Heefner, D. L.; Schiffer, C. A. Lack of synergy for inhibitors targeting a multi-drug-resistant HIV-1 protease. Protein Sci. 2002, 11, 418-429.

(39) Ozen, A.; Lin, K. H.; Kurt Yilmaz, N.; Schiffer, C. A. Structural basis and distal effects of Gag substrate coevolution in drug resistance to HIV-1 protease. Proc. Natl. Acad. Sci. U. S. A. 2014, 111, 1599315998.

(40) Barrie, K. A.; Perez, E. E.; Lamers, S. L.; Farmerie, W. G.; Dunn, B. M.; Sleasman, J. W.; Goodenow, M. M. Natural variation in HIV-1 protease, Gag p7 and p6, and protease cleavage sites within gag/pol polyproteins: amino acid substitutions in the absence of protease inhibitors in mothers and children infected by human immunodeficiency virus type 1. Virology 1996, 219, 407-416.

(41) Rose, J. R.; Salto, R.; Craik, C. S. Regulation of autoproteolysis of the HIV-1 and HIV-2 proteases with engineered amino acid substitutions. J. Biol. Chem. 1993, 268, 11939-11945.

(42) Hui, J. O.; Tomasselli, A. G.; Reardon, I. M.; Lull, J. M.; Brunner, D. P.; Tomich, C. S.; Heinrikson, R. L. Large scale purification and refolding of HIV-1 protease from Escherichia coli inclusion bodies. J. Protein Chem. 1993, 12, 323-327.

(43) Matayoshi, E. D.; Wang, G. T.; Krafft, G. A.; Erickson, J. Novel fluorogenic substrates for assaying retroviral proteases by resonance energy transfer. Science 1990, 247, 954-958.

(44) Liu, Y.; Kati, W.; Chen, C. M.; Tripathi, R.; Molla, A.; Kohlbrenner, W. Use of a fluorescence plate reader for measuring kinetic parameters with inner filter effect correction. Anal. Biochem. 1999, 267, 331-335.

(45) Lockbaum, G. J.; Leidner, F.; Rusere, L. N.; Henes, M.; Kosovrasti, K.; Nachum, G. S.; Nalivaika, E. A.; Ali, A.; Yilmaz, N. K.; Schiffer, C. A. Structural adaptation of darunavir analogues against 
primary mutations in HIV-1 protease. ACS Infect. Dis. 2019, 5, 316325.

(46) Soumana, D. I.; Kurt Yilmaz, N.; Ali, A.; Prachanronarong, K. L.; Schiffer, C. A. Molecular and dynamic mechanism underlying drug resistance in genotype 3 hepatitis C NS3/4A protease. J. Am. Chem. Soc. 2016, 138, 11850-11859.

(47) Otwinowski, Z.; Minor, W. Processing of X-ray diffraction data collected in oscillation mode. Methods Enzymol. 1997, 276, 307-326.

(48) McCoy, A. J.; Grosse-Kunstleve, R. W.; Adams, P. D.; Winn, M. D.; Storoni, L. C.; Read, R. J. Phaser crystallographic software. J. Appl. Crystallogr. 2007, 40, 658-674.

(49) Emsley, P.; Cowtan, K. Coot: Model-building tools for molecular graphics. Acta Crystallogr., Sect. D: Biol. Crystallogr. 2004, D60, 2126-2132.

(50) Adams, P. D.; Afonine, P. V.; Bunkoczi, G.; Chen, V. B.; Davis, I. W.; Echols, N.; Headd, J. J.; Hung, L.-W.; Kapral, G. J.; GrosseKunstleve, R. W.; McCoy, A. J.; Moriarty, N. W.; Oeffner, R.; Read, R. J.; Richardson, D. C.; Richardson, J. S.; Terwilliger, T. C.; Zwart, P. H. PHENIX: a comprehensive Python-based system for macromolecular structure solution. Acta Crystallogr., Sect. D: Biol. Crystallogr. 2010, 66, 213-221.

(51) Moriarty, N. W.; Grosse-Kunstleve, R. W.; Adams, P. D. electronic Ligand Builder and Optimization Workbench (eLBOW): a tool for ligand coordinate and restraint generation. Acta Crystallogr., Sect. D: Biol. Crystallogr. 2009, 65, 1074-1780.

(52) Brunger, A. T. Free R value: a novel statistical quantity for assessing the accuracy of crystal structures. Nature 1992, 355, 472475.

(53) Davis, I. W.; Leaver-Fay, A.; Chen, V. B.; Block, J. N.; Kapral, G. J.; Wang, X.; Murray, L. W.; Arendall, W. B.; Snoeyink, J.; Richardson, J. S.; Richardson, D. C. MolProbity: all-atom contacts and structure validation for proteins and nucleic acids. Nucleic Acids Res. 2007, 35, W375-W383.

(54) PyMOL: The PyMOL Molecular Graphics System, Version 2.1; Schrödinger, LLC.

(55) Schrödinger. Schrödinger Release 2018-3; Schrödinger, LLC, New York, NY, United States, 2018. 